Article

\title{
Comparative Assessment of Spatial Variability and Trends of Flows and Sediments under the Impact of Climate Change in the Upper Indus Basin
}

\author{
Waqas Ul Hussan ${ }^{1, *}$, Muhammad Khurram Shahzad ${ }^{2, *}$, Frank Seidel ${ }^{1}$, Anna Costa ${ }^{3}$ (D) and \\ Franz Nestmann 1 \\ 1 Institute for Water and River Basin Management, Karlsruhe Institute of Technology (KIT), Kaiserstr. 12, \\ 76131 Karlsruhe, Germany; Frank.Seidel@kit.edu (F.S.); franz.nestmann@kit.edu (F.N.) \\ 2 Department of Civil Engineering, Institute of Southern Punjab, Multan 60000, Pakistan \\ 3 Institute of Environmental Engineering, ETH Zurich, 8093 Zurich, Switzerland; anna.costa.pekar@gmail.com \\ * Correspondence: waqas.hussan@kit.edu (W.U.H.); shahzadmuhammadkhurram@gmail.com (M.K.S.)
}

Received: 1 January 2020; Accepted: 1 March 2020; Published: 6 March 2020

\begin{abstract}
Extensive research of the variability of flows under the impact of climate change has been conducted for the Upper Indus Basin (UIB). However, limited literature is available on the spatial distribution and trends of suspended sediment concentrations (SSC) in the sub-basins of UIB. This study covers the comparative assessment of flows and SSC trends measured at 13 stations in the UIB along with the variability of precipitation and temperatures possibly due to climate change for the past three decades. In the course of this period, the country's largest reservoir, Tarbela, on the Indus River was depleted rapidly due to heavy sediment influx from the UIB. Sediment management of existing storage and future planned hydraulic structures (to tap 30,000 MW in the region) depends on the correct assessment of SSC, their variation patterns, and trends. In this study, the SSC trends are determined along with trends of discharges, precipitation, and temperatures using the non-parametric Mann-Kendall test and Sen's slope estimator. The results reveal that the annual flows and SSC are in a balanced state for the Indus River at Besham Qila, whereas the SSC are significantly reduced ranging from $18.56 \%-28.20 \%$ per decade in the rivers of Gilgit at Alam Bridge, Indus at Kachura, and Brandu at Daggar. The SSC significantly increase ranging from $20.08 \%-40.72 \%$ per decade in the winter together with a significant increase of average air temperature. During summers, the SSC are decreased significantly ranging from $18.63 \%-27.79 \%$ per decade along with flows in the Hindukush and Western-Karakorum regions, which is partly due to the Karakorum climate anomaly, and in rainfall-dominated basins due to rainfall reduction. In Himalayan regions, the SSC are generally increased slightly during summers. These findings will be helpful for understanding the sediment trends associated with flow, precipitation, and temperature variations, and may be used for the operational management of current reservoirs and the design of several hydroelectric power plants that are planned for construction in the UIB.
\end{abstract}

Keywords: suspended sediment concentrations; Upper Indus Basin; Mann-Kendall trend test; Sen's slope estimator; Gilgit basin; Karakorum climate anomaly; Karakorum-Hindukush-Himalaya

\section{Introduction}

Erosion from the relatively younger mountain ranges of the Hindukush, Karakorum, and Himalaya yield a huge amount of sediment that enters the Upper Indus Basin (UIB) and its storage reservoirs, such as the Tarbela reservoir. Average sediment loads of 250 million tons per year are produced in the Indus River by these three mountain ranges, making it one of the world's largest sediment-laden 
rivers [1]. Sediment erosion is a rather complex phenomenon that primarily requires determination of parameters contained in universal soil loss equation. Recent research has covered the impacts of temperature-driven snow melt processes and patterns and climate change scenarios on the erosion rate in various catchments [2,3]. Erosion and sediment transport largely depend on hydrological and hydraulic parameters that are largely driven and/or altered by climate forces. Knowledge about the distribution of hydro-meteorological parameters and sediment yields and their magnitude variations over time is crucial to the partial validation of the impacts of climate change. The assessment and quantification of variations of fluvial sediment fluxes and their spatiotemporal patterns are important for a better understanding of river geomorphology as well as the planning, design, and operation of hydraulic structures on the river. The variation of sediment fluxes affects the depletion of reservoirs, channel erosion and deposition, abrasion of hydropower turbines, pollution of river ecosystems, and the operation and management of hydropower as well as storage reservoirs. Assessment of spatio-temporal variation of suspended sediment concentrations (SSC) or yields due to precipitation, temperature, and flow process variations are vital to adapt watershed management practices and to better understand the landslide activities in the basin.

Pakistan's economy is based on agriculture. Agricultural production contributes $18.9 \%$ of the gross domestic product (GDP) in Pakistan and makes up the major part of the country's annual exports. Pakistan is among the top ten world water stressed countries due to the vulnerability of climate changes, reduction of storages, increase of its population, and increase of water demands [4,5]. The Tarbela reservoir, which lies in the UIB, has lost $35 \%$ of its capacity since 1974 due to reservoir sedimentations [6]. This rapid depletion of storage reservoirs due to siltation not only affects the country's economy, but also endangers food security and leads to cross-border water conflicts. Post construction measures against siltation in reservoirs are indispensable, but sometimes neither technically nor financially feasible. Sedimentation also adversely affects the ecosystems of both rivers and reservoirs. To enhance the sustainability and environmental compatibility of existing reservoirs and hydropower projects planned in the UIB, the impact of climate change on both flows and suspended sediments concentrations (SSC) has to be assessed. This assessment may improve the understanding of the effects of the Karakorum climate anomaly $[7,8]$ on the seasonal and annual trends of flows and sediment yields in the UIB. This could also be beneficial for the management of sediments. This study will also help to understand the effect of different hydrological processes, such as snow cover, snow melt, ice melt, and rainfall, on erosion and sediment yield in sub-basins of the UIB dominated by snow and ice melting.

Many techniques, statistical methods, and approaches have been used by a lot of researchers for assessing changes in climate, flows, and SSC. The moving $t$-test, Yamonato method, Carner method, order clustering approach, and filter test method were used in the past $[9,10]$. The parametric regression approach was applied to determine the discharge-total suspended solids relationships (Q-TSS)/SSC vs. time-discharge (T-Q) for the trend analysis of sediments [11]. In 1945, Mann and Kendall suggested the nonparametric test method for time series analysis [12]. Gerstengarbe and Werner developed the Mann-Kendall test to analyze and detect trends [13]. Furthermore, the rank sum test [14], two-sample $t$-test [15], and Pettit test [16] were used for trend analysis in many studies. In a recent study for the Loess Plateau [17], trend analysis was carried out as well, because the plateau contributes $80 \%$ of the sediment belonging to the Yellow River. For large basins like the Indus basin, the analysis and budgeting of sediments and their patterns require huge resources and a large data collection expenditure. A few years ago, sediment studies were carried out [18-20] on the UIB. These studies covered the sediment patterns, sediment distribution, and sediment budgeting on the basin scale. Sediment transport is a highly nonlinear and complex phenomenon due to multiple factors controlling and affecting the erosion process, such as channel erosion, gully erosion, snow and glacier melts erosion etc. To characterize the highly nonlinear processes of sediment erosion, flow, and climate change, most researchers have used the non-parametric test. It is the most powerful tool to assess the temporal and spatial dynamics of sediment fluxes, hydrological variables, and climate. For the trends of nonlinear processes, such as flows, climate, and sediment yields, the Mann-Kendall trend test is 
used for this study. It is a robust method and has the capacity to detect the trends of time series without considering the normal distribution of the input datasets. In a regional study [21], the non-parametric Mann-Kendall test was used to detect the trends of flows and sediment discharges in the Yellow River. Similarly, the non-parametric Mann-Kendall test was applied for the trend analysis of sediment yields based on data from a few stations in the UIB in two recent studies [22,23]. According to the experience gained by many researchers, however, the Mann-Kendall test alone, and without considering the serial/auto correlations, is insufficient to detect trends. Therefore, the trend-free pre-whitening (TFPW) approach, along with the Mann-Kendall trend test, is used here to detect the trends of flows, SSC, and climatic parameters. To further quantify the magnitudes of the trends of hydro-climatic time series, Sen's slope estimator is used after the trend-free pre-whitening (TFPW) and Mann-Kendall trend analysis. Several hydropower stations and storage reservoirs are planned to be constructed in the UIB according to the 2025-2030 vision of the Water and Power Development Authority (WAPDA). The comprehensive assessment of the trends of flows and suspended sediment concentrations (SSC) under the impact of climate change for all 13 gauging stations in the Hindukush, Karakorum, and Himalaya mountain ranges presented in this study will be particularly helpful for policymakers, hydraulic engineers, and water resources managers. Therefore, the objectives of this study are: (1) the detection and assessment of trends in different temporal intervals ranging from monthly to seasonal and annual basis for flows and SSC of the 13 hydrological stations in the UIB since 1980-2010; (2) development of seasonal and annual trend maps for representing the spatial changes in \% for flows and SSC per decade in the UIB; (3) extracting the missing year's climatic information for sparsely gauged climatic stations using the linear scaling bias correction method along with the station-recorded data and satellite grid point data; (4) assessment of the impact of changes in the trends of mean monthly rainfalls of the basins and average monthly temperatures, adjusted for lapse rate per elevation zone, on the monthly flows and SSC of the UIB; (5) assessing the significant changes in monthly, seasonal, and annual flows and SSC, which are partly due to climate change, in past 30 years for selected catchments with major SSC contributions.

\section{Materials}

\subsection{Study Area}

The Indus River is among the largest rivers in South Asia with its total length of $2880 \mathrm{~km}[24,25]$. It has a total catchment area of $970,468 \mathrm{~km}^{2}$ with about $56 \%\left(529,134 \mathrm{~km}^{2}\right)$ of its area lying within the territory of Pakistan. The remaining catchment area is distributed between China, India, and Afghanistan. It also has the world's largest irrigation networks covering an irrigated agricultural area of 181,000 km² [26,27]. Moreover, the Indus basin is an economic source of energy. Hydropower produced here has a share of $29 \%$ in the total national power generation capacity of Pakistan [27].

This study focuses on the Upper Indus Basin (UIB) upstream of the Tarbela dam with a total catchment area of $172,000 \mathrm{~km}^{2}$ and a length of $1125 \mathrm{~km}[18,28]$. The watershed area of the UIB upstream of the Tarbela reservoir is situated at $31^{\circ}-37^{\circ} \mathrm{E}$ and $72^{\circ}-82^{\circ} \mathrm{N}$. The watershed elevation of the UIB above the Tarbela dam ranges from 360 to $8572 \mathrm{~m}$ above mean sea level [28]. The detailed characteristics of the gauging stations measuring flows and SSC at 13 locations in the UIB are given in the Table 1. Four gauging stations are located on the main arm of the Upper Indus, eight on the tributaries, and one station, Alam Bridge, at the confluence of two tributaries.

Figure 1 shows the details of the catchment area, the sub-basins, and the tributaries of the UIB. It starts from the frozen planes of the Tibetan Plateau in China. Then, it enters from the south eastern direction in a well-defined valley and flows parallel to the geological fault line. After crossing the fluvial plains $45 \mathrm{~km}$ upstream of Skardu town at an altitude of $2469 \mathrm{~m}$, it joins Shyok River with $30 \%$ of glacier drainage area. Here, the valley widens and mostly consists of sediments in the form of glacial deposits down to Skardu town. Upstream of Skardu in the Deosai plains, the Kharmong River from 
the central Himalayas lying in Pakistan joins the main (Indus) River with a total glacier-covered area of $4 \%$. Kharmong River is dominated by a snow and rainfall flow regime.

Table 1. Geographical characteristics of the stream gauging sites measuring flows and suspended sediment concentrations (SSC) in the Upper Indus Basin (UIB).

\begin{tabular}{|c|c|c|c|c|c|c|}
\hline Ser \# & $\begin{array}{c}\text { Discharge Gauging } \\
\text { Stations }\end{array}$ & Region & $\begin{array}{l}\text { Catchment } \\
\text { Area km² }\end{array}$ & $\begin{array}{l}\text { Elevation } \\
(\mathrm{m})\end{array}$ & $\begin{array}{l}\text { Elevation } \\
\text { Range (m) }\end{array}$ & $\begin{array}{c}\% \text { of Glacier } \\
\text { Cover }\end{array}$ \\
\hline 1 & Hunza at Dainyor & Western Karakorum & 13,157 & 1350 & $1426-7860$ & 35 \\
\hline 2 & Gilgit at Gilgit & Hindukush & 12,095 & 1430 & $1454-7048$ & 10 \\
\hline 3 & Gilgit at Alam Bridge & Hunza + Gilgit & 26,159 & 1280 & $1266-7843$ & 25 \\
\hline 4 & Indus at Kharmong & Central Himalayas & 67,858 & 2542 & $2478-7036$ & 4 \\
\hline 5 & Shyok at Yogu & Eastern Karakorum & 33,670 & 2469 & $2397-7553$ & 30 \\
\hline 6 & Shigar at Shigar & Central Karakorum & 6610 & 2438 & $2191-7793$ & 39 \\
\hline 7 & Indus at Kachura & Main River UIB & 112,665 & 2341 & $2107-7801$ & 12 \\
\hline 8 & Astore at Doyian & $\begin{array}{l}\text { Northwestern } \\
\text { Himalayas }\end{array}$ & 4040 & 1583 & $1580-8058$ & 8 \\
\hline 9 & $\begin{array}{c}\text { Indus at Partab } \\
\text { Bridge/Bunji }\end{array}$ & Main River UIB & 142,709 & 1228 & $1242-7889$ & 11 \\
\hline 10 & Indus at Shatial Br. & Main River UIB & 150,220 & 1040 & $906-8118$ & 12 \\
\hline 11 & Indus at Besham Qila & Main River UIB & 162,393 & 580 & $561-8118$ & 13 \\
\hline 12 & Lower UIB at Daggar & Lower western UIB & 598 & 700 & $685-2801$ & 0 \\
\hline 13 & Lower UIB at Karora & Lower western UIB & 635 & 880 & 893-4439 & 1 \\
\hline
\end{tabular}

Near the town of Skardu, the Shigar River with 39\% of glacier-covered area from the Himalayas drains into the main (Indus) River at an altitude of $2438 \mathrm{~m}$. Downstream of Skardu town, the main River flows towards the Northwest up to Kachura Lake along the steep and narrow valley of the main River. The Hunza River runs from North to South and Gilgit River runs from the Northwest to Southeast before confluence at Alam Bridge just downstream of Gilgit town. Hunza Basin borders with Shigar Basin on the right side in the direction of flow. Hunza and Gilgit Rivers are snow- and glacier-dominated basins lying in the Western Karakorum and Hindukush mountain ranges with 39\% and $10 \%$ of glacier-covered area, respectively. Astore River also joins the main River. It comes from the western Himalayas with $8 \%$ of glacier-covered area north of the Nanga Parbat massif. Downstream of Alam Bridge, the confluence of Gilgit and Hunza Rivers join the main Indus River at Bunji/Partab Bridge in Jaglot town. Jaglot is a monumental place, where all three great mountain ranges, the Himalayas, Karakorum, and Hindukush, meet. The lower part of the UIB starts at Bunji and extends up to Tarbela dam. The main river widens between Alam Bridge and Chillas and contains sediments in the form of glacier deposits. The Indus River continues its journey towards Shatial Bridge. From Shatial Bridge, the main river flows further towards the South in a steep and narrow cross section and joins Besham Qila, approx. $45 \mathrm{~km}$ upstream of the Tarbela reservoir. Near Besham Qila, some small and large rivers also join the Indus from both the left and the right side. The right tributaries joining the main Indus River near Besham Qila are Brandu, Gorband, Khan Khawar, Duber Khwar, Keyal Khwar, Kandia, and Tangir. The left tributaries joining the main Indus River near Besham Qila are Siran, Chor Nullah, Spat Gah, Allai Khwar, Gunar Gah, Thor Gah, and Butto Gah. 

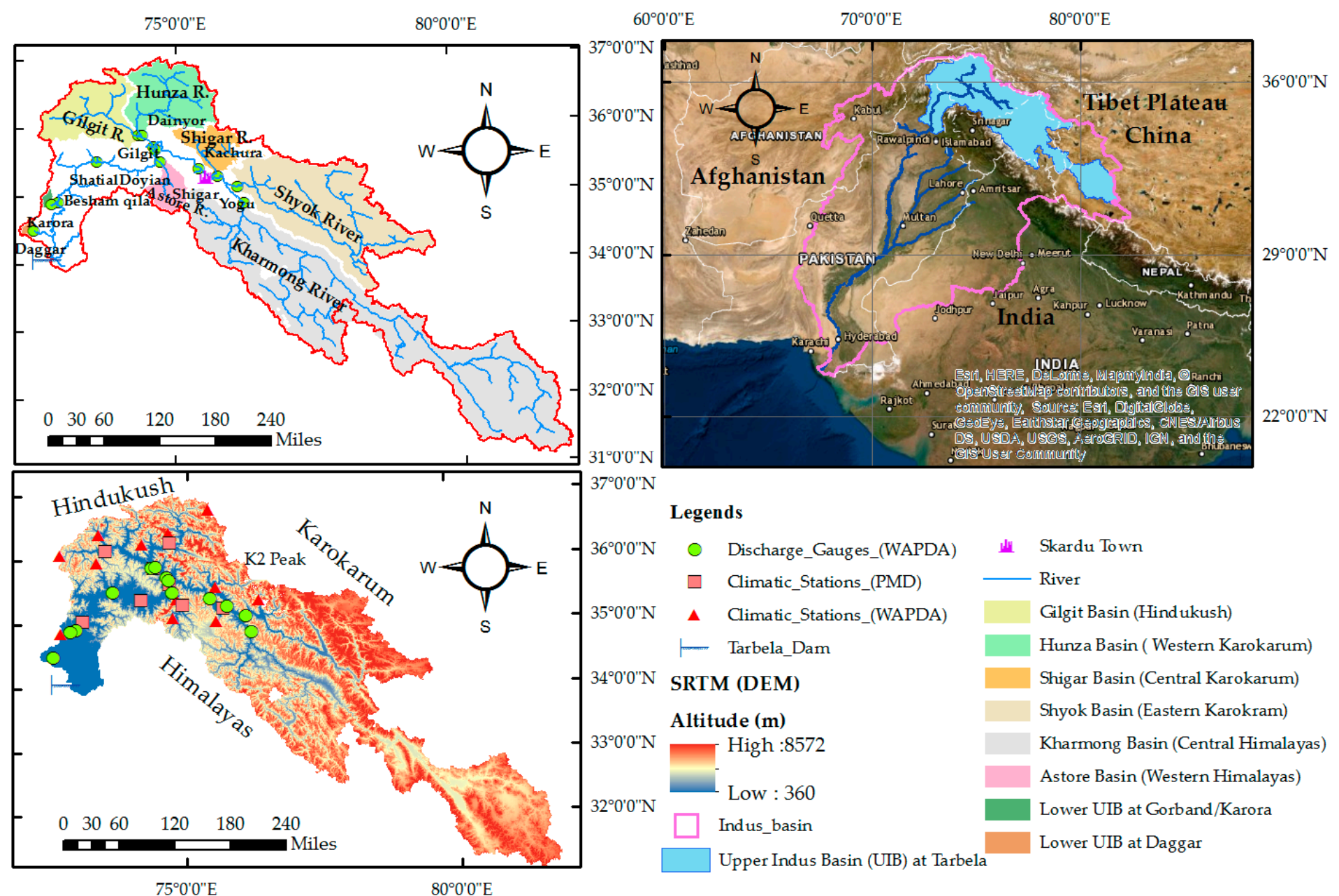

$37^{\circ} 0^{\prime} 0^{\prime \prime}$

\section{Legends}

$36^{\circ} 0^{\circ} 0^{\prime \prime} \mathrm{N} \bigcirc$ Discharge_Gauges_(WAPDA) 业 Skardu Town

$\square$ Climatic_Stations_(PMD)

$35^{\circ} 0^{\prime} 0^{\prime \prime} \mathrm{N}$

\.Climatic_Stations_(WAPDA)

$\vdash$ Tarbela_Dam

Gilgit Basin (Hindukush)

\section{$34^{\circ} 0^{\prime} 0 " \mathrm{~N}$ SRTM (DEM)}

\section{Altitude (m)}

$33^{\circ} 0^{\prime} 0^{\prime \prime} \mathrm{N}$ High :8572

Low : 360

Hunza Basin ( Western Karokarum)

Shigar Basin (Central Karokarum)

Shyok Basin (Eastern Karokram)

Kharmong Basin (Central Himalayas)

$2^{\circ} 0^{\prime} 0^{\prime \prime N}$

$75^{\circ} 0^{\prime} 0 " \mathrm{E}$

$80^{\circ} 0^{\prime} 0^{\prime \prime E}$

$\square$ Indus_basin $\quad$ Lower UIB at Gorband/Karora

Astore Basin (Western Himalayas)

Figure 1. The map of the study area shows the locations of stream gauges, climatic stations, and sub-basins contributing to the Upper Indus Basin (UIB). 
The climate of the UIB comprises two climatic fronts. One is the monsoon pattern of rainfall that originates from the Bay of Bengal and Arabian Sea. The second is the westerlies climatic front originating from the Caspian Sea and Mediterranean region during winters and springs. Most of the annual precipitation in the UIB falls in the form of snow during the winter and spring season due to westerlies [29,30]. Mean annual precipitation in Gilgit ranges from $150 \mathrm{~mm}$ at lower elevations to $1800 \mathrm{~mm}$ in the snow accumulation zone in Bagrot valley [31]. In the Western Karakorum over the Batura glaciers, annual precipitation accounts for more than $1000 \mathrm{~mm}$ [32]. In the Central Karakorum, annual precipitation ranges from $1000 \mathrm{~mm}$ to more than $2000 \mathrm{~mm}$ over the Hispar and Biafo glaciers [33]. In the Central Karakorum, $67 \%$ of annual precipitation fall during winter is due to the westerly front, with the remaining $33 \%$ of annual rainfall during the summer season $[7,34,35]$. In the lower UIB, annual rainfall ranges from $1000 \mathrm{~mm}$ to $1500 \mathrm{~mm}$ between Dasu and Besham Qila [23]. In the UIB, the maximum mean basin rainfall occurs during the spring season, with April being the month of highest rainfall [36].

In the UIB the upper glaciered has very low population density $\left(<50\right.$ people $\left.\mathrm{km}^{2}\right)$ in comparison to the lower monsoon dominated region. The upper region of UIB has an estimated population of 1.5 Million. The lower region of UIB is vice versa. The upper region of UIB also has high percent of snow/ice cover, at up to $40 \%$ in Hunza, Gilgit, Shigar, and Shyok river basins. This snow/ice cover emerges as a single dominated land cover factor which explains $73.4 \%$ of the variance in sediment yields for whole UIB [37].

The trends induced by climate change on the discharges of various sub-catchments have been widely reported by many researchers $[7,8,38,39]$, however, scientific literature on the spatio-temporal variation of SSC is far less extensive. Ali and De Boer [18] analyzed the spatial distribution of sediment in the UIB by dividing the region into three zones: upper snow- and glacial melt-dominated zone, middle snow-/glacial melt-, and rainfall-dominated mixed zone, and lower rainfall-dominated zone. Ateeq-Ur-Rehman et al. and Tarar et al. [22,23] identified the trends of SSC by using the data of two and four gauging stations of the UIB, respectively. Meanwhile, the former used the SSC of Hunza basin at Danyor, Shyok basin at Yogu, Upper Indus at Bunji/Partab Bridge, and Upper Indus at Besham Qila. They have used data from the gauge of Partab Bridge for the melt portion of the UIB and from Besham Qila to represent the load of the entire UIB. These studies found a significant inter-annual shift of SSC with the balanced annual sediment yield. However, an assessment of the spatio-temporal variation of SSC and discharges in relation to relevant hydrometeorological parameters and variables for all the sub-basins of the entire UIB has not yet been made. This study therefore covers the trends of spatial variability of SSC and discharges in the UIB using the data of 13 gauging stations located in the Karakorum, Himalayan, and Hindukush regions that represent almost the entire UIB with its eight sub-catchments (Table 1). Moreover, the previous studies used daily sediment values derived from discharge-sediment rating curves (SRC) and artificial neural networks (ANN) [22,23]. The SRC and databased models give highly overestimated and underestimated values and sometimes negative values, which are physically not possible. Especially, for the highly glacier and snow melt basins, the SRC are not reliable. In comparison to previous researches in the region that mainly relied on discharge-sediment rating curves (SRC) and artificial neural networks (ANN) for SSC, the mean of monthly sediments was taken by averaging the daily SSC gauged data. Thereby, SRC values were only used in those months where no information of sediment concentrations was available. This study is also one of the pioneer researches that used corrected estimates of rainfall and temperature for the assessment of comparative trends of precipitation, temperature, and SSC in the UIB [40,41].

\subsection{Data Collection}

For the present study, the data of 13 stream gauges in the UIB for the period 1981-2010 were collected within the Surface Water Hydrology Project (SWHP) of the Water and Power Development Authority (WAPDA). These stations measure flows on a daily basis and SSC on intermittent days. 
A rating curve was used to find the missing values of SSC for monthly, seasonal, and annual trend analysis. The list and characteristics of these stations are given in Table 2.

Hunza is second largest glacier-dominated basin of the UIB in the Western Karakorum. Here, data are available for the period of 1981-2010. The Hunza River generates $12 \%$ and $12.5 \%$ of the Besham Qila flows and suspended sediment loads (SSL), respectively. The Gilgit station at Gilgit lies in the Hindukush mountain range draining the Gilgit river basin. Here, data are available for 1981-2010. Its flows and SSL are $12 \%$ and 3.9\% of the Besham Qila flows and SSL, respectively. Gilgit station is important due to the contribution of snow melt, ice melt, and rainfall to flows and SSL. The Alam Bridge station is located at the confluence of Gilgit River and Hunza River, generating 26\% and 18.2\% of Besham Qila flows and SSL, respectively. The major influx of sediment from the Hunza River raises the SSL in the combined flow of Gilgit and Hunza at Alam Bridge.

The gauge at Kharmong in the Central Himalayas was installed in 1982. For this reason, data of flows and SSC are available for the period 1983-2010. The main River comes from the Deosai plain and is dominated by snow melt and rainfall. Its flows and SSL are $18 \%$ and $7 \%$ of the Besham Qila flows and SSL, respectively. The Yogo station on Shyok River lies in the eastern Karakorum. Shyok River originates from the Tibetan Plateau in China and has the third largest glacier dominance in the UIB. Data are available for the period 1981-2010. The station measures $16 \%$ and $20.6 \%$ of flows and SSL, respectively, of Besham Qila. The Shigar station in the Central Karakorum generates most of the flows and SSL due to largest glacier dominance in the UIB. The station was installed in 1982, but data are available from 1985-1998 only. After 1998, Shigar station was not in operation. Its flows and SSL are $9 \%$ and $15.4 \%$ of the Besham Qila flows and SSL, respectively.

The Indus at Kachura contributes $48 \%$ and $52.1 \%$ to the Besham Qila flows and SSL, respectively. Data are available for the long term from 1981-2010. The Bunji/Partab Bridge station on the main River has data from 1981 to June 2010. Due to the 2010 flood, the gauging site was destroyed, and the data of the remaining six months of 2010 are lacking. The Bunji station generates $71 \%$ and $97.6 \%$ of the flows and SSL, respectively, of Besham Qila. The river here contains the water and sediments from glacierand snow-dominated upstream basins, i.e., Hunza and Gilgit on upper Northeastern side and from the parallel basins of Shigar, Shyok, and Kharmong on the lower Northeastern end. The Doyian station on Astore River also is located in a snow melt- and rainfall-dominated basin in the Western Himalayas. It generates $6 \%$ and $1.2 \%$ of the flows and SSL, respectively, of Besham Qila. Again, data are available for the entire period of 1981-2010.

The station Shatial Bridge was installed in 1983 and measures $87 \%$ of flows and surprisingly $70.0 \%$ of SSL of Besham Qila despite its location downstream of the Bunji station. Hydrological data of Shatial are available from 1983-2010. The Daggar station on Brandu River is the right tributary of the Lower UIB near Besham Qila. It is a rainfall-dominated basin contributing $0.4 \%$ and $0.4 \%$ of discharges and SSL, respectively, of Besham Qila. The Karora station of the Gorband basin is also is located on a right tributary near Besham Qila and contributes $0.7 \%$ and $0.2 \%$ of flows and SSC, respectively, of Besham Qila. Both Daggar and Karora measured data in the period from 1981-2010. 
Table 2. Hydrological characteristics of discharge gauging stations in the Upper Indus Basin (UIB).

\begin{tabular}{|c|c|c|c|c|c|c|c|c|c|c|c|}
\hline Ser \# & $\begin{array}{c}\text { Discharge Gauging } \\
\text { Stations }\end{array}$ & Region & Lat. $\left({ }^{\circ}\right)$ & Long. $\left({ }^{\circ}\right)$ & Period & Flows $\left(\mathrm{m}^{3} / \mathrm{sec}\right)$ & $\begin{array}{l}\mathrm{SSC} \\
(\mathrm{mg} / \mathrm{L})\end{array}$ & $\begin{array}{l}\% \text { of UIB } \\
\text { Flows }\end{array}$ & $\begin{array}{l}\% \text { of UIB } \\
\text { SSC }\end{array}$ & $\begin{array}{c}\text { SSL (Million } \\
\text { Tons/Year) }\end{array}$ & $\begin{array}{l}\% \text { of UIB } \\
\text { SSL }\end{array}$ \\
\hline 1 & Hunza at Dainyor & Western Karakorum & 35.92 & 74.37 & $1981-2010$ & 297 & 1091 & 12 & 125 & 33 & 12.5 \\
\hline 2 & Gilgit at Gilgit & Hindukush & 35.92 & 74.3 & 1981-2010 & 293 & 442 & 12 & 51 & 10 & 3.9 \\
\hline 3 & Gilgit at Alam Bridge & Hunza + Gilgit & 35.76 & 74.59 & 1981-2010 & 632 & 795 & 26 & 91 & 48 & 18.2 \\
\hline 4 & Indus at Kharmong & Central Himalayas & 34.93 & 76.21 & 1983-2010 & 453 & 669 & 18 & 76 & 19 & 7.0 \\
\hline 5 & Shyok at Yogu & Eastern Karakorum & 35.18 & 76.1 & 1981-2010 & 390 & 1305 & 16 & 150 & 54 & 20.6 \\
\hline 6 & Shigar at Shigar & Central Karakorum & 35.33 & 75.75 & 1985-1998 & 223 & 2395 & 9 & 275 & 40 & 15.4 \\
\hline 7 & Indus at Kachura & Main River UIB & 35.45 & 75.41 & 1981-2010 & 1192 & 1171 & 48 & 134 & 137 & 52.1 \\
\hline 8 & Astore at Doyian & $\begin{array}{l}\text { North Western } \\
\text { Himalayas }\end{array}$ & 35.54 & 74.7 & 1981-2010 & 140 & 295 & 6 & 34 & 3 & 1.2 \\
\hline 9 & $\begin{array}{l}\text { Indus at Partab } \\
\text { Bridge/Bunji }\end{array}$ & Main River UIB & 35.73 & 74.62 & $1981-2010$ & 1757 & 1019 & 71 & 117 & 257 & 97.6 \\
\hline 10 & Indus at Shatial Br. & Main River UIB & 35.53 & 73.56 & 1983-2010 & 2167 & 919 & 87 & 106 & 185 & 0.70 \\
\hline 11 & Indus at Besham Qila & Main River UIB & 34.92 & 72.88 & 1981-2010 & 2479 & 870 & 100 & 100 & 263 & 100.0 \\
\hline 12 & Lower UIB at Daggar & Lower western UIB & 34.49 & 75.46 & 1981-2010 & 9.9 & 547 & 0.4 & 63 & 1 & 0.4 \\
\hline 13 & Lower UIB at Karora & Lower western UIB & 34.89 & 72.76 & $1981-2010$ & 18 & 355 & 0.7 & 41 & 0.4 & 0.2 \\
\hline
\end{tabular}

Note: The flows and SSC are instantaneous values for the time the water samples are taken by sediment sampler. 
The SSC data given in \% of Besham Qila benchmarks do not only reflect the availability of suspended sediment, but also indicate the transport capacity. For example, Shigar at Shigar, Shyok at Yogu, and Hunza at Dainyor report 2.75, 1.50, and 1.25 times the suspended sediment concentration of Besham Qila, respectively. Similarly, the Indus at Kachura (134\%), Partab Bridge $(117 \%)$, and Shatial Bridge (106\%) is found to contain more suspended sediment than recorded at Besham Qila, which indicates that with the increasing flows from Kachura to Besham Qila, the suspended sediment does not match with the increasing rate of discharges. However, the SSL data reveal that from Kachura to Bunji, the sediment increases from 137 to 257 million tons, but decreases to 185 million tons at Shatial, and again rises to 263 Million tons at Besham Qila. Provided that the data are correct, the decrease of sediment load from Bunji to Shatial despite the increasing discharges means that sediment is being deposited between Bunji and Shatial and there may be either channel bed erosion or an addition of suspended sediments from the lateral tributaries between Shatial and Besham Qila, which makes the SSL more than double at the tail end.

The daily climatic data of rainfall and temperatures from 18 meteorological stations in the UIB were also collected in this study. The meteorological stations of Skardu, Gilgit, Gupis, Astore, Bunji, and Chillas are operated by the Pakistan Meteorological Department (PMD).

The remaining climatic stations under the supervision of the Water and Power Development Authority (WAPDA) have been recording data since 1995. Table 3 presents the details of these climatic stations. In addition, the grid data of precipitation and temperature of $5 \times 5 \mathrm{~km}$ resolution determined in the HI-AWARE project for the Indus, Ganges, and Brahmaputra river basins were collected [40,41]. The Shuttle Radar Topography Mission's (SRTM) digital elevation model (DEM) data of 30-m resolution were applied as well. The mean basin precipitation data were extracted from the corrected rainfall data of the HI-AWARE project using DEM. The temperature data of higher elevated gauges for the missing period from 1981-1994 were extracted from grid data and corrected with station observations by using the linear biased scaling method. Estimation of glacier areas was based on the glacier polygons of the Global Land Ice Measurement (GLIMS) database. In this study, DEM is used to estimate the glacier area for each sub-basin from downloaded GLIMS polygons [42].

Table 3. Characteristics of climatic gauging stations in the Upper Indus Basin (UIB).

\begin{tabular}{|c|c|c|c|c|c|c|}
\hline Discharge Outlet & Region & $\begin{array}{l}\text { Climatic } \\
\text { Stations }\end{array}$ & Lat. $\left({ }^{\circ}\right)$ & Long. $\left({ }^{\circ}\right)$ & $\begin{array}{c}\text { Average } \\
\text { Altitude (m) }\end{array}$ & Period \\
\hline \multirow{3}{*}{ Hunza at Dainyor } & \multirow{3}{*}{ Western Karakorum (WK) } & Naltar & 36.29 & 74.12 & 2898 & 1995-2010 \\
\hline & & Ziarat & 36.47 & 74.62 & 3020 & 1995-2010 \\
\hline & & Khunjrab & 36.83 & 75.4 & 4440 & 1995-2010 \\
\hline \multirow{5}{*}{ Gilgit at Gilgit } & \multirow{5}{*}{ Hindukush (HK) } & Gilgit & 34.92 & 73.34 & 1460 & 1981-2010 \\
\hline & & Gupis & 36.17 & 73.4 & 2156 & 1981-2010 \\
\hline & & Ushkore & 35.99 & 73.25 & 3051 & 1995-2010 \\
\hline & & Yasin & 36.43 & 73.27 & 3280 & 1995-2010 \\
\hline & & Shendure & 36.09 & 72.54 & 3712 & 1995-2010 \\
\hline $\begin{array}{l}\text { Gilgit at Alam } \\
\text { Bridge }\end{array}$ & Hunza + Gilgit & $\mathrm{HK}+\mathrm{WK}$ & - & - & - & 1981-2010 \\
\hline Indus at Kharmong & Central Himalayas $(\mathrm{CH})$ & Desosai & 35.09 & 75.54 & 4149 & 1995-2010 \\
\hline Shyok at Yogu & Eastern Karakorum (EK) & Hushey & 35.42 & 76.37 & 3075 & 1995-2010 \\
\hline \multirow{2}{*}{ Shigar at Shigar } & \multirow{2}{*}{ Central Karakorum (CK) } & Shigar & 35.63 & 75.53 & 2325 & 1995-2010 \\
\hline & & Skardu & 35.3 & 75.68 & 2210 & 1981-2010 \\
\hline Indus at Kachura & Main River UIB & $\mathrm{EK}+\mathrm{CH}$ & - & - & - & 1981-2010 \\
\hline $\begin{array}{l}\text { Indus at Partab } \\
\text { Bridge/Bunji }\end{array}$ & $\begin{array}{c}\text { Main River UIB }(\mathrm{HK}+\mathrm{WK} \\
+\mathrm{CK}+\mathrm{EK}+\mathrm{CH})\end{array}$ & Bunji & 35.67 & 74.64 & 1372 & $1981-2010$ \\
\hline \multirow{3}{*}{ Astore at Doyian } & \multirow{3}{*}{$\begin{array}{c}\text { North Western Himalayas } \\
\text { (NWH) }\end{array}$} & Astore & 35.34 & 74.9 & 2168 & 1981-2010 \\
\hline & & Raitu & 35.14 & 74.73 & 2718 & 1995-2010 \\
\hline & & Rama & 35.43 & 74.79 & 3179 & 1995-2010 \\
\hline
\end{tabular}


Table 3. Cont.

\begin{tabular}{ccccccc}
\hline Discharge Outlet & Region & $\begin{array}{c}\text { Climatic } \\
\text { Stations }\end{array}$ & Lat. $\left(^{\circ}\right)$ & Long. $\left(^{\circ}\right)$ & $\begin{array}{c}\text { Average } \\
\text { Altitude (m) }\end{array}$ & Period \\
\hline Indus at Shatial Br. & $\begin{array}{c}\text { Main River UIB (HK + WK } \\
+ \text { CK + EK + CH) }\end{array}$ & Chillas & 35.42 & 74.1 & 1250 & $1981-2010$ \\
\hline $\begin{array}{c}\text { Indus at } \\
\text { Besham Qila }\end{array}$ & $\begin{array}{c}\text { Main River UIB (HK + WK } \\
+ \text { CK + EK + CH) }\end{array}$ & Chillas & 35.67 & 74.64 & 1250 & $1981-2010$ \\
\hline $\begin{array}{c}\text { Lower UIB at } \\
\text { Daggar }\end{array}$ & Lower western UIB & Shangla & 34.87 & 72.6 & 1960 & $1995-2010$ \\
\hline $\begin{array}{c}\text { Lower UIB at } \\
\text { Karora }\end{array}$ & Lower western UIB & Shangla & 34.87 & 72.6 & 1960 & $1995-2010$ \\
\hline
\end{tabular}

\section{Methods}

The data outliers in this study do not affect the analysis, as the Mann-Kendall test used for trend analysis is non-parametric. The homogeneity of the mean annual flows and SSC was checked using the standard normal homogeneity test (SNHT) and Buishand's range (BR) test at 5\% significance level for each station. The flows and suspended sediments are considered homogeneous when the critical values of SNHT and BR are $\mathrm{T}_{0}<9.17, \mathrm{Q} \sqrt{ } \mathrm{n}<1.27$, and $\mathrm{R} \sqrt{ } \mathrm{n}<1.55$. $\mathrm{T}_{0}$ is SNHT test statistics. Similarly $\mathrm{Q} / \sqrt{ } \mathrm{n}$ and $\mathrm{R} / \sqrt{\mathrm{n}}$ are BR test statistics. Table 4 shows the results of the SNHT and BR tests.

Table 4. Characteristics of climatic gauging stations in the Upper Indus Basin (UIB).

\begin{tabular}{|c|c|c|c|c|c|c|c|}
\hline \multirow{3}{*}{ Sr \# } & \multirow{3}{*}{ Station } & \multicolumn{3}{|c|}{ Stream Flows $\left(\mathrm{m}^{3} / \mathrm{sec}\right)$} & \multicolumn{3}{|c|}{ Suspended Sediments (mg/L) } \\
\hline & & \multirow{2}{*}{$\begin{array}{c}\text { SNHT } \\
\mathrm{T}_{0}\end{array}$} & \multicolumn{2}{|c|}{$\begin{array}{c}\text { Buishand's Range (BR) } \\
\text { Test }\end{array}$} & \multirow{2}{*}{$\begin{array}{c}\text { SNHT } \\
\mathrm{T}_{0}\end{array}$} & \multicolumn{2}{|c|}{$\begin{array}{c}\text { Buishand's Range (BR) } \\
\text { Test }\end{array}$} \\
\hline & & & $\frac{Q}{\sqrt{n}}$ & $\frac{R}{\sqrt{n}}$ & & $\frac{Q}{\sqrt{n}}$ & $\frac{R}{\sqrt{n}}$ \\
\hline 1 & Hunza at Dainyor & 4.37 & 0.1 & 1.33 & 4.98 & 0.09 & 1.04 \\
\hline 2 & Gilgit at Gilgit & 4.32 & 0.08 & 0.85 & 2.19 & 0.05 & 1.13 \\
\hline 3 & Gilgit at Alam Bridge & 3.29 & 0.06 & 0.98 & 4.36 & 0.08 & 0.98 \\
\hline 4 & Indus at Kharmong & 3.55 & 0.10 & 1.5 & 3.51 & 0.10 & 1.42 \\
\hline 5 & Shyok at Yogu & 2.42 & 0.06 & 0.97 & 5.68 & 0.10 & 1.91 \\
\hline 6 & Shigar at Shigar & 4.50 & 0.13 & 0.99 & 3.00 & 0.12 & 1.18 \\
\hline 7 & Indus at Kachura & 1.97 & 0.06 & 1.16 & 7.09 & 0.11 & 1.25 \\
\hline 8 & $\begin{array}{l}\text { Indus at Partab } \\
\text { Bridge/Bunji }\end{array}$ & 4.37 & 0.07 & 0.85 & 3.07 & 0.06 & 1.05 \\
\hline 9 & Astore at Doyian & 5.92 & 0.07 & 0.85 & 3.83 & 0.08 & 1.08 \\
\hline 10 & Indus at Shatial Br. & 1.33 & 0.05 & 0.74 & 5.01 & 0.11 & 1.34 \\
\hline 11 & Indus at Besham Qila & 1.23 & 0.05 & 0.83 & 3.31 & 0.06 & 1.14 \\
\hline 12 & Lower UIB at Daggar & 1.58 & 0.06 & 0.96 & 5.98 & 0.11 & 1.28 \\
\hline 13 & Lower UIB at Karora & 12.59 & 0.17 & 1.8 & 11.39 & 0.05 & 0.97 \\
\hline
\end{tabular}

Note: For homogeneous data series $\mathrm{T}_{0}<9.17, \frac{\mathrm{Q}}{\sqrt{n}}<1.27$, and $\frac{\mathrm{R}}{\sqrt{n}}<1.55$.

\subsection{Statistical Methods}

The Mann-Kendall trend test is applied to detect the trends for mean values of flow, SSC, precipitation, and average temperatures on a monthly, seasonal, and annual basis. Before applying the Mann-Kendall test, the time series data were analyzed to check serial correlation. The serial correlations were eliminated from the series using the trend-free pre-whitening (TFPW) approach.

\subsubsection{Serial Correlation and Trend-Free Pre-Whitening (TFPW)}

Serial correlation in time series is defined as correlation of a variable with itself over successive time intervals. This correlation must be removed before trend analysis [43]. Removal of this correlation is important, because it significantly affects the results of the non-parametric test during trend analysis. 
Using the two-tailed test of autocorrelation coefficient $\left(\mathrm{r}_{1}\right)$ at a $5 \%$ significance level, the time series of flows, SSC, rainfall, and temperatures were checked for serial correlation as:

$$
\mathrm{r}_{1}=\frac{\sum_{\mathrm{i}=1}^{\mathrm{n}-1}\left(\mathrm{X}_{\mathrm{i}}-\mathrm{X}^{-}\right)\left(\mathrm{X}_{\mathrm{j}+1}-\mathrm{X}^{-}\right)}{\sum_{\mathrm{i}=1}^{\mathrm{n}}\left(\mathrm{X}_{\mathrm{i}}-\mathrm{X}^{-}\right)^{2}}
$$

where $X_{i}$ is the value of suspended sediments at ith time interval and $X^{-}$is the mean value of sediments. $\mathrm{n}$ is the number of years.

The value of the autocorrelation coefficient $r_{1}$ at $95 \%$ of confidence interval in the two-tailed test is given as:

$$
\mathrm{r}_{1} \text { Suspended Sediments }(95 \%)=\frac{-1 \pm 1.96 \sqrt{(\mathrm{n}-2)}}{\mathrm{n}-1}
$$

The trend-free pre-whitening (TFPW) approach is proposed when the $\mathrm{r}_{1}$ value of the time series lies between the upper and lower limits of the confidence interval [44].

\subsubsection{Mann-Kendall Test}

The Mann-Kendall test is most widely used for the trend analysis of hydro-climatic data in various studies [12,45-47]. To detect the statistically significant trends in the time series, the Mann-Kendall test uses two hypotheses. The null hypothesis $\left(\mathrm{H}_{0}\right)$ is that there is no trend overtime in flows and suspended sediment data. The $\left(\mathrm{H}_{1}\right)$ hypothesis is that the trend in the time series is increasing or decreasing.

For the Mann-Kendall test $[12,45,47], \mathrm{S}$ has been computed as given below:

$$
\mathrm{S}=\sum_{\mathrm{i}=1}^{\mathrm{n}-1} \sum_{\mathrm{j}=\mathrm{i}+1}^{\mathrm{n}} \operatorname{sig}\left(\mathrm{X}_{\mathrm{j}}-\mathrm{X}_{\mathrm{i}}\right)
$$

As $X_{i}$ and $X_{j}$ are the data values at times $i$ and $j$, while $n$ is the length of the dataset.

$$
\operatorname{Sgn}\left(X_{j}-X_{i}\right)=\left\{\begin{array}{c}
+1 \text { if }\left(X_{j}-X_{i}\right)>0 \\
0 \text { if }\left(X_{j}-X_{i}\right)=0 \\
-1 \text { if }\left(X_{j}-X_{i}\right)<0,
\end{array}\right.
$$

The positive values of the calculated $\mathrm{S}$ indicate the positive trend and vice versa.

The variance $S$ of data series is computed by the equation given below:

$$
\operatorname{Var}(S)=\frac{1}{18}\left[n(n-1)(2 n+5)-\sum_{p=1}^{q} t_{p}\left(t_{p}-1\right)\left(2 t_{p}+5\right)\right]
$$

where $t_{p}$ is the number of ties for $p$ th values with $q$ being the number of tied values. After calculating the variance $\operatorname{Var}(\mathrm{S})$ of data time series, the standard $\mathrm{Z}$ value is calculated as

$$
Z=\left\{\begin{array}{l}
\frac{s-1}{\sqrt{\operatorname{Var}(S)}} \text { if } S>0 \\
0 \text { if } S=0 \\
\frac{s+1}{\sqrt{\operatorname{Var}(S)}} \text { if } S<0
\end{array}\right.
$$

The calculated positive value of $Z$ indicates an increasing trend, while a negative value of $Z$ reflects a decreasing trend.

The $Z$ value is compared at a significant level of $\alpha=1 \%, 5 \%$, and $10 \%$ with the normal distribution table value. The null hypothesis $\left(\mathrm{H}_{0}\right)$ is rejected, if the $\mathrm{Z}$ value is greater than $\left|\mathrm{Z}_{1-\frac{\alpha}{2}}\right|,|\mathrm{z}|>\left|\mathrm{Z}_{1-\frac{\alpha}{2}}\right|$, where $\left|Z_{1-\frac{\alpha}{2}}\right|$ was obtained from the standard normal distribution table. The other hypothesis $\mathrm{H}_{1}$ is accepted. 


\subsubsection{Sen's Slope Estimator}

To quantify the magnitude of change of the trend in time series data, the Sen's slope estimation method [48] was used.

$$
Q_{i}=\frac{X_{j}-X_{k}}{j-k}
$$

where $Q_{i}$ is the slope of the ith paired of data, for $i=1, \ldots, N$

$X_{j}$ and $X_{k}$ are the data values at the time of $j$ and $k[j>k]$, respectively. The median of $N$ values of $Q_{i}$ values is the Sen's slope estimator given as

$$
\mathrm{Q}_{\mathrm{i}}=\left\{\begin{array}{c}
\mathrm{T}_{\frac{(\mathrm{N}+1)}{2}} \mathrm{~N} \text { is odd } \\
\frac{1}{2}\left(\mathrm{~T}_{\frac{\mathrm{N}}{2}}+\mathrm{T}_{\frac{(\mathrm{N}+1)}{2}}\right) \mathrm{N} \text { is even }
\end{array}\right.
$$

\section{Results}

\subsection{Preliminary Analysis}

The preliminary descriptive statistics for discharge and SSC are given in Table 5. Besham Qila station that represents the snow- and ice melt-dominated and partly rainfall-dependent basins shows the highest values of mean (Mean), minimum (Min), and maximum (Max) flows due to the fact it is the last gauging station of the UIB that is located just upstream of the Tarbela reservoir. Shatial Bridge just upstream of Besham Qila shows the highest standard deviation (Std.) of discharges, which means that the flow pattern is more erratic than at both neighboring upstream and downstream stations. Daggar, the basin dominated by high-intensity rainfall in spring and summer, is comparatively small and reports the highest values for the coefficient of variations ( $\mathrm{Cv}(\%))$, coefficient of skewness (Cs), and coefficient of kurtosis (Ck) for discharges partly because of the low mean magnitude and high discharge variations because of rainfall storms. Daggar basin also shows the lowest minimum and maximum flows due to rainfall contribution only and the small catchment area. Gorband at Karora shows the lowest standard deviation. Besham Qila, Partab Bridge, and Kachura on the main Indus River are found to have the lowest coefficient of variations, coefficient of skewness, and coefficient of skewness, respectively. This is due to the fact that they represent very large catchments (Table 1).

Shigar, the glacier-dominated basin, shows the highest values of mean, maximum, and standard deviation of SSC, followed by Shyok, Kachura, and Hunza. The Indus at Shatial Bridge reaches the highest values of minimum of SSC, which may possibly be due to heterogeneous spells of channel erosion of glacier deposits. During low flow season these glacier deposits might be transported by increase of winter discharges in channel. The Gorband at Karora is found to have the highest coefficient of variations, which could be probably due to the operation of a lot of upstream micro hydropower stations installed by the community. Gilgit, the snow melt-, ice melt-, and rainfall-dominated basin, reaches the highest coefficient of skewness and coefficient of kurtosis of SSC, which may probably be due to dominant snow melts in the basin and increased sediment transport from the upstream catchment. Astore at Doyian, a snowfall-dominated basin, is found to have the lowest SSC in terms of mean, maximum, and standard deviation. Besham Qila shows the lowest coefficient of variations, which is attributed to the fact that it is last downstream station of the UIB, where river hydraulics is the predominant factor rather than upstream catchment erosions. Moreover, the representation of a larger catchment is less prone to variations by short-term local forcings. Hunza at Dainyor shows the lowest value of coefficient of skewness. Probably, more sediments are deposited in the upstream valley and hydraulics of the river with effective discharges from the glacier melts is more dominant, which ensures steady sediment transport. The Indus at Kachura shows the lowest coefficient of skewness, probably due to high flows and steady SSC contribution along narrow river valleys with less glacier deposits in the channel. It must be noted that flow doubles and SSC is reduced by almost a quarter from Kachura to Besham Qila along the main arm of the Indus River, which means that 
either the lateral sub-basin downstream of Kachura yields less suspended sediment in comparison to discharges or there is an issue of sediment transport capacity in a reach between these stations.

Table 5. Summary of descriptive statistics of the selected discharge and sediment gauging stations.

\begin{tabular}{|c|c|c|c|c|c|c|c|c|}
\hline $\mathrm{Sr} \#$ & Gauging Stations & Mean & Min & Max & Std. & $\mathrm{Cv}(\%)$ & Cs & Ck \\
\hline \multicolumn{9}{|c|}{ Discharge $\mathrm{m}^{3} / \mathrm{sec}$} \\
\hline 1 & Hunza at Dainyor & 296.75 & 50.73 & 508.21 & 96.59 & 32.55 & -0.37 & 1.58 \\
\hline 2 & Gilgit at Gilgit & 293.21 & 83.14 & 867.86 & 122.76 & 41.87 & 3.42 & 16.67 \\
\hline 3 & Gilgit at Alam Bridge & 632.39 & 217.61 & 1215.64 & 185.44 & 29.32 & 0.58 & 3.12 \\
\hline 4 & Indus at Kharmong & 452.78 & 118.94 & 782.45 & 140.29 & 30.98 & 0.17 & 1.09 \\
\hline 5 & Shyok at Yogu & 390.07 & 180.28 & 545.96 & 89.29 & 22.89 & -0.15 & -0.36 \\
\hline 6 & Shigar at Shigar & 223.25 & 142.06 & 330.64 & 57.44 & 25.73 & 0.29 & -0.65 \\
\hline 7 & Indus at Kachura & 1192.19 & 860.16 & 1547.26 & 197.44 & 16.56 & 0.09 & -0.77 \\
\hline 8 & $\begin{array}{c}\text { Indus at Partab } \\
\text { Bridge/Bunji }\end{array}$ & 1756.94 & 865.51 & 2256.72 & 369.38 & 21.02 & -0.81 & 0.3 \\
\hline 9 & Astore at Doyian & 139.9 & 37.52 & 232.24 & 38.58 & 27.58 & -0.22 & 0.94 \\
\hline 10 & Indus at Shatial & 2167.32 & 915.99 & 2981.57 & 499.73 & 23.06 & -0.58 & 0.28 \\
\hline 11 & Indus Besham Qila & 2479.37 & 1858.22 & 3304.93 & 378.85 & 15.28 & 0.37 & -0.55 \\
\hline 12 & Lower UIB at Daggar & 13.84 & 3.81 & 129.3 & 21.85 & 157.9 & 5.23 & 28.41 \\
\hline 13 & Lower UIB at Karora & 18.1 & 5.89 & 37.36 & 7.24 & 40 & 0.97 & 1.26 \\
\hline \multicolumn{9}{|c|}{ Suspended Sediments $\mathrm{mg} / \mathrm{L}$} \\
\hline 1 & Hunza at Dainyor & 1091.44 & 53.75 & 2244.65 & 568.27 & 52.07 & 0.03 & -0.04 \\
\hline 2 & Gilgit at Gilgit & 441.98 & 76.82 & 2169.5 & 410.59 & 92.9 & 2.78 & 9.94 \\
\hline 3 & Gilgit at Alam Bridge & 795.32 & 114.47 & 1971.58 & 439.5 & 55.26 & 0.86 & 0.53 \\
\hline 4 & Indus at Kharmong & 668.9 & 138.28 & 2150.42 & 537.79 & 80.4 & 1.37 & 1.21 \\
\hline 5 & Shyok at Yogu & 1305.08 & 128.78 & 5219.85 & 1208.13 & 92.57 & 1.79 & 2.96 \\
\hline 6 & Shigar at Shigar & 2395.08 & 257.48 & 7571.67 & 1883.03 & 78.62 & 1.6 & 3.64 \\
\hline 7 & Indus at Kachura & 1171.27 & 131.29 & 2390.97 & 554.23 & 47.32 & 0.36 & -0.16 \\
\hline 8 & $\begin{array}{c}\text { Indus at Partab } \\
\text { Bridge/Bunji }\end{array}$ & 1019.35 & 306.92 & 3294.93 & 658.31 & 64.58 & 1.79 & 4.21 \\
\hline 9 & Astore at Doyian & 295.27 & 96.8 & 675.68 & 164.53 & 55.72 & 0.94 & 0.04 \\
\hline 10 & Indus at Shatial & 919 & 352.8 & 1993.22 & 355.1 & 38.64 & 1.32 & 2.34 \\
\hline 11 & Indus at Besham Qila & 870.71 & 322.08 & 1584.57 & 286.96 & 32.97 & 0.43 & 0.63 \\
\hline 12 & Lower UIB at Daggar & 546.85 & 76.8 & 1649.01 & 401.73 & 73.46 & 1.43 & 1.85 \\
\hline 13 & Lower UIB at Karora & 355.03 & 48 & 1739.6 & 417.81 & 117.68 & 2.17 & 4.54 \\
\hline
\end{tabular}

Note: Red color shows highest values and blue color indicates the lowest values for both flows and SSC.

\subsection{Monthly, Seasonal, and Annual Trends of Discharges}

Using longer time steps, such as decadal accumulative discharges, means to avoid inter-annual fluctuations when determining long-term trends for the Indus basin [22,49]. In this study, monthly trends of discharges $\left(\mathrm{m}^{3} / \mathrm{sec}\right)$ with $90 \%$ confidence interval are determined per decade by using the Sens's slope estimator after the Mann-Kendall trend test, as shown in Table 6. For the flows, most of the stations show increasing trends of discharges in snow- and glacier-dominated basins in the months of from December to June but decreasing discharges in July-August on higher altitudes like Hunza and Kharmong. The Indus at Besham Qila (main UIB), Shatial Bridge (main UIB), Partab Bridge (main UIB), and Kachura (main UIB) and the Astore at Doyian (Western Himalayas) reveal increasing trends of flows per decade in most of the months between November and April. Most of the remaining glacierand snow-dominated basins, such as Gilgit (Hindukush), Hunza (Western Karakorum), Shigar (Central Karakorum), and Shyok (Western Karakorum), show a significant increase of flows between October and March. However, the Kharmong (Central Himalayas) exhibits a mixed trend in these months. 
Table 6. Mann-Kendall trends for monthly time series data and Sen's slope estimates.

\begin{tabular}{|c|c|c|c|c|c|c|c|c|c|c|c|c|}
\hline $\begin{array}{c}\text { Discharge Gauging } \\
\text { Stations }\end{array}$ & January & February & March & April & May & June & July & August & September & October & November & December \\
\hline \multicolumn{13}{|c|}{ Change in Discharge $\mathrm{m}^{3} / \mathrm{sec}$ per Decade } \\
\hline Hunza at Dainyor & 0.87 & 0.89 & 0.66 & 6.35 & -2.27 & 12.13 & -28.64 & $-174.58 *$ & 5.17 & 1.71 & $5.11 *$ & -1.68 \\
\hline Gilgit at Gilgit & 0.29 & 0.09 & 0.9 & 5.36 & $55.82 *$ & 33.09 & 53.44 & 2.22 & 13.32 & $19.44 *$ & 5.6 & $7.39 *$ \\
\hline Gilgit at Alam Bridge & 1.1 & 1.3 & 2.74 & $19.82 *$ & 19.47 & $109.07^{*}$ & 21.57 & 9.62 & 71.52 & $31.03 *$ & $18.9^{*}$ & 12.44 \\
\hline Indus at Kharmong & -1.44 & 0.34 & 4.88 & 5.49 & -20.82 & -3.24 & -167.82 & -7.03 & -41.29 & 16.33 & 7.74 & -1.58 \\
\hline Shyok at Yogu & $2.13 *$ & 2.25 * & 0.09 & -1.59 & 6.41 & 58.34 & 78.54 & 88.74 & 12.55 & $31.21 *$ & $10.3^{*}$ & 2.01 \\
\hline Shigar at Shigar & 1.76 & 2.98 & $8.74 *$ & 9.58 & -13.7 & 176.1 & 432.67 & $376.17 *$ & 33.78 & -2.54 & -1.43 & -1.24 \\
\hline Indus at Kachura & 4.9 & $10.55^{*}$ & $10.42 *$ & 2.74 & 43.95 & 78.62 & 279.97 & 78.77 & $-175.18 *$ & 11.71 & 4.69 & 7.43 \\
\hline $\begin{array}{l}\text { Indus at Partab } \\
\text { Bridge/Bunji }\end{array}$ & 13.8 & $20.27^{*}$ & $24.19 *$ & $46.93 *$ & $149.07^{*}$ & 323.34 & 425.22 & 135.27 & 27.06 & 7.72 & $27.44^{*}$ & 14.59 \\
\hline Astore at Doyian & $2.62 *$ & $2.76^{*}$ & $3.93 *$ & $13.86^{*}$ & $39.44 *$ & 22.06 & -6.72 & 7.77 & 2.01 & 2.66 & 3.57 & $3.57 *$ \\
\hline Indus at Shatial Br. & $44.17^{*}$ & $35.96 *$ & $36.19 *$ & $88.64 *$ & 239.08 & 174.8 & 173.35 & 234 & 71.2 & 63.88 & $37.11 *$ & $43.67 *$ \\
\hline Indus at Besham Qila & $36.31 *$ & $41.08 *$ & $30.48 *$ & 6.96 & 170.34 & 16.31 & 214.18 & 125 & 163.75 & $95.17^{*}$ & $57.61 *$ & $35.84 *$ \\
\hline Lower UIB at Daggar & 0.33 & $0.55 *$ & $-4.31 *$ & -0.2 & 0.1 & $0.4^{*}$ & -1.45 & -3.25 & 0.01 & 0.15 & 0.07 & 0.2 \\
\hline Lower UIB at Karora & -0.04 & 1.51 & -2.81 & $-7.01 *$ & $-7.88^{*}$ & $-3.77 *$ & $-5.73 *$ & $-4.88 *$ & $-2.77 *$ & -0.78 & -0.52 & -1.44 \\
\hline \multicolumn{13}{|c|}{ Change in Suspended Sediments mg/L per Decade } \\
\hline Hunza at Dainyor & 24.03 & 8.34 & 42.5 & -91.58 & 3.67 & 738.07 & -765 & -1181.35 & -12.73 & -35.72 & 15 & $8.67^{*}$ \\
\hline Gilgit at Gilgit & 15 & $15.89 *$ & $17.5^{*}$ & 18.86 & 45.53 & -68.77 & -245.43 & $-472.47^{*}$ & -24.57 & -0.21 & $15.38 *$ & $17.82 *$ \\
\hline Gilgit at Alam Bridge & $25^{*}$ & $16.65^{*}$ & 32.81 & -9.45 & -31.76 & 68.82 & $-591.67 *$ & $-858.57^{*}$ & $-115 *$ & -9.05 & $46.82 *$ & $36.75^{*}$ \\
\hline Indus at Kharmong & -56.95 & -22.21 & 23.93 & $86.05^{*}$ & 62.67 & 376.84 & $-110.4 *$ & -15.11 & -167.62 & -14.53 & 2.09 & -5.62 \\
\hline Shyok at Yogu & 8.49 & -16.34 & 33.98 & $108.57^{*}$ & 43.86 & $-458.54 *$ & -34.56 & -385.34 & -63.93 & 5.21 & 13.84 & 32.15 \\
\hline Shigar at Shigar & 34.3 & 74.56 & 13.89 & 96.5 & 201.25 & 1104.17 & -2175.64 & 58.3 & 712.78 & 198.34 & 625.42 & 87.68 \\
\hline Indus at Kachura & -42.86 & -52.18 & 71.56 & $-156.76^{*}$ & -179.95 & 39.87 & $-699.07^{*}$ & -667.87 & -462.05 & -103.08 & -103.85 & -75.11 \\
\hline $\begin{array}{l}\text { Indus at Partab } \\
\text { Bridge/Bunji }\end{array}$ & $25.61 *$ & $42.75^{*}$ & $28.52 *$ & $37.15^{*}$ & -108.62 & 154.05 & 137.87 & -201.63 & -230.23 & 14.17 & 2.55 & $20.53 *$ \\
\hline Astore at Doyian & $21.09 *$ & $32.34 *$ & 8.69 & $45.49^{*}$ & $60.98^{*}$ & 13.55 & -41.11 & -13.91 & $54.9^{*}$ & 19.53 & $22.15^{*}$ & 17.5 \\
\hline Indus at Shatial Br. & $50 *$ & $38.61 *$ & $95 *$ & $146.1^{*}$ & $117.97^{*}$ & -141.98 & 174.12 & 411.86 & $-11.62 *$ & -0.96 & 23.22 & 24.88 \\
\hline Indus at Besham Qila & $9.01 *$ & 4.56 & 6.07 & 13.04 & $182.16^{*}$ & 142.51 & -34.44 & -222.47 & 26.9 & -18.22 & 0.32 & 1.28 \\
\hline Lower UIB at Daggar & 3.58 & -8.16 & $-64.75 *$ & $-54.38 *$ & $-16.14 *$ & -21.98 & $-544.84 *$ & $-219.64 *$ & -67.85 & 0.87 & 1 & 12.6 \\
\hline Lower UIB at Karora & 5.79 & 7.54 & $-34.13 *$ & -31.57 & -5.66 & 2.25 & -57.05 & 11.96 & 6.71 & -4.07 & 3.45 & 16.6 \\
\hline
\end{tabular}

Note: * significant level $90 \%$, negative values are in bold. 
The Kharmong (Central Himalayas) station shows a significant decrease of flows during the months of December, January, May, and June. In the Lower UIB, the rainfall-dominated Brandu basin at Daggar and Gorband basin at Karora (both in the Lower UIB in the West) mostly show significantly decreasing trends of discharges in the months between December and June. During the months of July, August, and September, an insignificant weak increase or decrease in flows is observed in most of the snow- and glacier-dominated basin. The Hunza at Dainyor (Western Karakorum) and Indus at Kachura (main UIB), however, show significantly decreasing trends of flows in the months of August and September. The lower UIB basins exhibit decreasing trends of flow during the months from July to September. The Gorband basin at Karora (Lower UIB in the West) shows a significant decrease of flows in the months from July to September. In the months of October and November, flows are generally increasing in all the basins except for the Shigar basin.

Table 7, Figure 2 and Figure 4a show the percentage of seasonal and annual changes in mean values of flows on a temporal and spatial basis in the UIB. The winter discharges of the Indus River at Besham Qila (main UIB), Shatial Bridge (main UIB), Partab Bridge (main UIB), and Kachura (main UIB) and of the Astore River at Doyian (Western Himalayas) increase significantly by 3.3-8.5\% per decade. The spring discharges of the main (Indus) River at Shatial Bridge (main UIB) and Partab Bridge (main UIB) and of Astore River at Doyian (Western Himalayas) are also significantly increased by 3.3-8.5\% per decade. In the Lower UIB, however, the spring discharges of Gorband at Karora (Lower UIB in the West) are reduced significantly by up to $20 \%$ of the mean values contrary to the basins containing water from glacier and snow melting. During the summers, there are no significant changes in flows of snow- and glacier-dominated basins except for the Shigar basin. In the Brandu at Daggar and Gorband at Karora (both Lower UIB in the West) the summer flows decrease significantly by up to $23 \%$ per decade in both basins. During the autumns, the flows at Besham Qila (main UIB) increase significantly by up to $7.27 \%$ per decade, whereas the autumn discharges are reduced significantly in Brandu River at Daggar.

Table 7. Annual and seasonal percentage changes per decade for mean of data periods.

\begin{tabular}{|c|c|c|c|c|c|c|}
\hline Sr \# & $\begin{array}{c}\text { Discharge Gauging } \\
\text { Stations }\end{array}$ & DJF (\%) & MAM (\%) & JJA (\%) & SON (\%) & Annual (\%) \\
\hline \multicolumn{7}{|c|}{ Per Decade \% of Change in Discharge for Average Data Periods } \\
\hline 1 & Hunza at Dainyor & 0.41 & -2.74 & -4.25 & -1.26 & -7.64 \\
\hline 2 & Gilgit at Gilgit & 3.27 & 14.16 & 4.18 & 5.66 & 5.85 \\
\hline 3 & Gilgit at Alam Bridge & -0.46 & $3.33^{*}$ & 4.13 & 7.93 & 4.29 \\
\hline 4 & Indus at Kharmong & -1.95 & 2.41 & -4.42 & -1.55 & -5.37 \\
\hline 5 & Shyok at Yogu & 4.36 & -1.88 & 9.1 & 8.67 & 3.35 \\
\hline 6 & Shigar at Shigar & 8.74 & 25.52 & $47.88^{*}$ & 16.11 & $35.38 *$ \\
\hline 7 & Indus at Kachura & $3.32^{*}$ & 4.3 & 5.28 & $-10.37^{*}$ & 0.6 \\
\hline 8 & $\begin{array}{l}\text { Indus at Partab } \\
\text { Bridge/Bunji }\end{array}$ & $3.51^{*}$ & 9.6 * & 3.18 & 0.44 & 1.14 \\
\hline 9 & Astore at Doyian & $8.22 *$ & $18.59 *$ & 0.96 & 2.1 & 8.84 \\
\hline 10 & Indus at Shatial Br. & $8.49 *$ & $13.58 *$ & 3.96 & -0.42 & -1.49 \\
\hline 11 & Indus at Besham Qila & $6.95 *$ & 5.82 & 0.42 & $7.27 *$ & -0.71 \\
\hline 12 & Lower UIB at Daggar & 6.62 & -19.8 & $-23.61 *$ & -0.65 & $-18.30 *$ \\
\hline 13 & Lower UIB at Karora & -4.84 & $-19.82 *$ & $-22.92 *$ & $-17.89 *$ & $-20.34 *$ \\
\hline
\end{tabular}


Table 7. Cont.

\begin{tabular}{|c|c|c|c|c|c|c|}
\hline Sr \# & $\begin{array}{c}\text { Discharge Gauging } \\
\text { Stations }\end{array}$ & DJF (\%) & MAM (\%) & JJA (\%) & SON (\%) & Annual (\%) \\
\hline \multicolumn{7}{|c|}{ Per Decade \% of Change in Suspended Sediments for Average Data Periods } \\
\hline 1 & Hunza at Dainyor & $20.08 *$ & -0.84 & -18.53 & -7.6 & -17.66 \\
\hline 2 & Gilgit at Gilgit & $20.27 *$ & 3.98 & $-27.79 *$ & -2.52 & -10.28 \\
\hline 3 & Gilgit at Alam Bridge & $29.03 *$ & 2.57 & $-18.63 *$ & $-21.37 *$ & $-18.56 *$ \\
\hline 4 & Indus at Kharmong & 3.39 & 16.49 & 10.91 & -11.73 & 2.46 \\
\hline 5 & Shyok at Yogu & 2.52 & 8.85 & -6.59 & -3.68 & -14.29 \\
\hline 6 & Shigar at Shigar & 1.89 & 6.55 & -17.3 & 42.87 & -2.2 \\
\hline 7 & Indus at Kachura & -12.77 & -5.96 & $-23.84 *$ & $-27.87 *$ & $-24.06 *$ \\
\hline 8 & $\begin{array}{c}\text { Indus at Partab } \\
\text { Bridge/Bunji }\end{array}$ & $28.76^{*}$ & -2.01 & -3.97 & -6.57 & -9.43 \\
\hline 9 & Astore at Doyian & $31.86 *$ & $14.6 *$ & 4.93 & 18.19 & 11.87 \\
\hline 10 & Indus at Shatial Br. & $40.72 *$ & $33.11 *$ & 7.68 & -2.84 & 5.75 \\
\hline 11 & Indus at Besham Qila & 2.68 & $19.9 *$ & -5.75 & 1.8 & -4.51 \\
\hline 12 & Lower UIB at Daggar & 0.84 & $-16.88 *$ & $-24.85 *$ & $-15.56 *$ & $-28.2 *$ \\
\hline 13 & Lower UIB at Karora & 5.05 & -5.73 & -1.38 & -2.44 & -0.74 \\
\hline
\end{tabular}

Note: * significant level $90 \%$, negative values are in bold.

On an annual basis, flows of glacier- and snow-dominated basins do not change significantly, except for the Shigar basin. However, the annual discharges of the rainfall-dominated Brandu at Daggar and Gorband at Karora are reduced significantly by up to $20 \%$ per decade. 

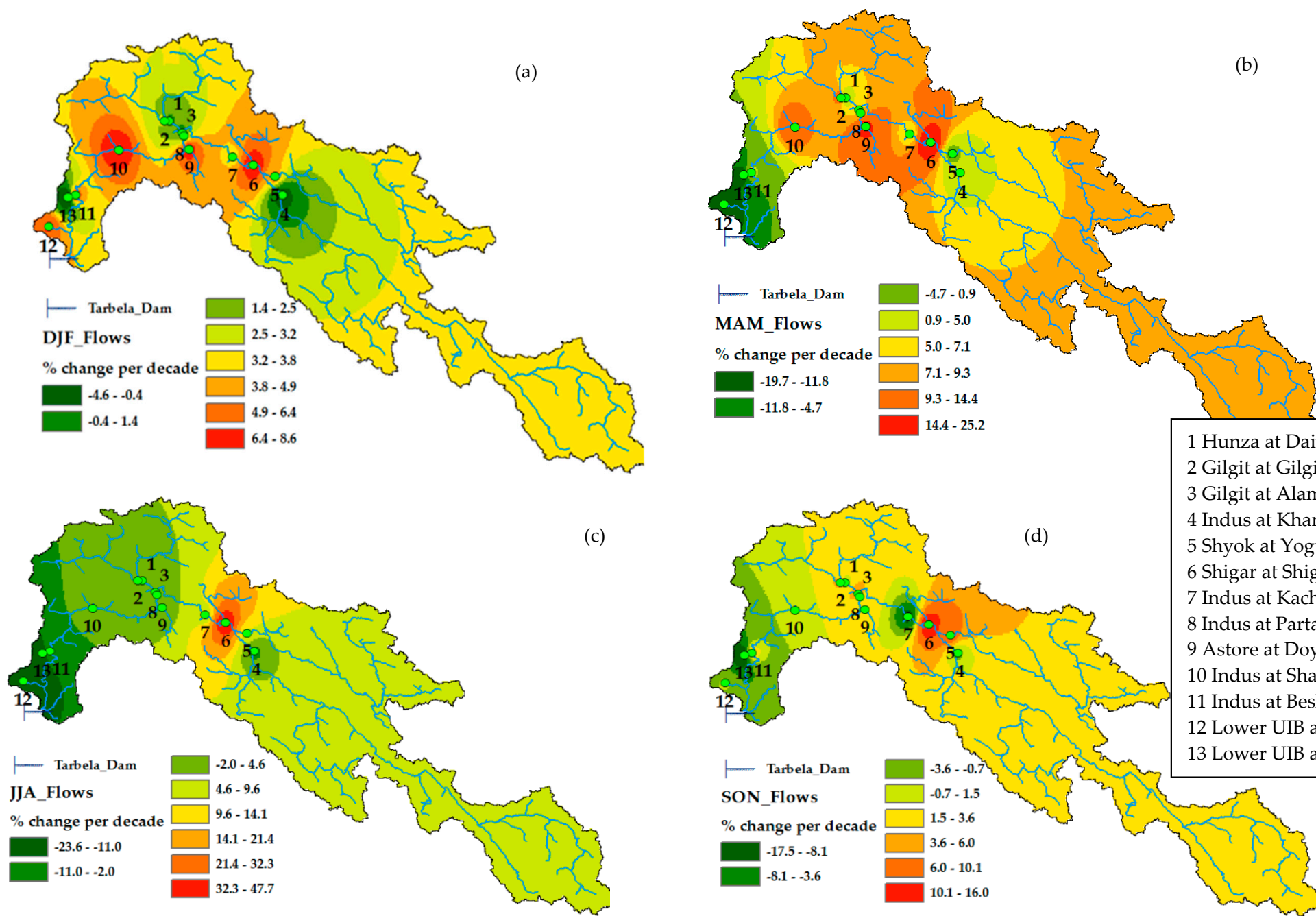

\begin{tabular}{l|l}
$-11.8--4.7$ & $9.3-14.4$ \\
& \\
&
\end{tabular}

1 Hunza at Dainyo 2 Gilgit at Gilgit 3 Gilgit at Alam Bridge

4 Indus at Kharmong

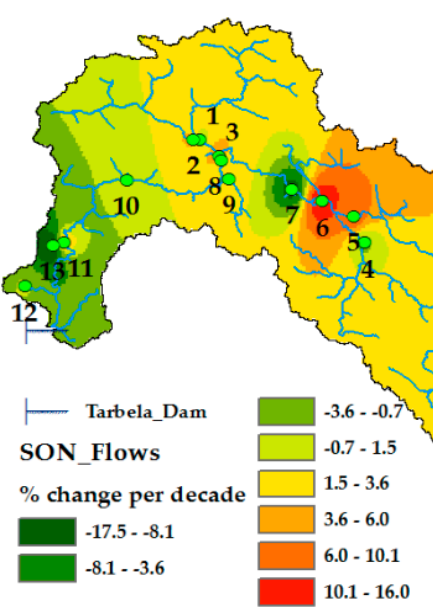

5 Shyok at Yogu

6 Shigar at Shigar

7 Indus at Kachura

8 Indus at Partab Bridge/Bunji

9 Astore at Doyian

10 Indus at Shatial Br.

11 Indus at Besham Qila

12 Lower UIB at Daggar

13 Lower UIB at Karora

Figure 2. Seasonal flow trends spatially distributed over the basin with \% of changes per decade in \% of mean values for the whole period. (a) DJF (winter), (b) MAM (spring), (c) JJA (summer), (d) SON (autumn) seasons. 


\subsection{Monthly, Seasonal, and Annual Trends of Suspended Sediment Concentrations (SSC)}

Table 6 shows the monthly trends of suspended sediment concentrations (SSC) (mg/L) with $90 \%$ significance level, which have been obtained by using the Sens's slope estimation method. In the months from December to May the trends of SSC are mixed in upper sub-basins of the UIB. However, most of the stations located on snow- and glacier-dominated basins show an increase of the SSC from December to May along with, though disproportionate, positive discharge trends. The Indus at Partab Bridge (main UIB) and Shatial Bridge (main UIB), Astore River at Doyian (Western Himalayas), and Gilgit at Alam Bridge (Gilgit + Hunza) show significantly increasing trends of SSC (mg/L) and discharges per decade in the months between December and June. Similarly, Gilgit River at Gilgit (Hindukush) exhibits a major increase of SSC in the months of December, February, and March. The Indus at Besham Qila shows a significant increase of SSC per decade in the months of December and May. In contrast to this, the Indus at Kharmong (Central Karakorum) and Kachura (main UIB) shows an insignificant reduction of SSC in the months of December, January, and February. Contrary to the upper sub-basins of the UIB, where the SSC is increased in the months from December to May, the Lower UIB exhibits decreased SSC and discharges in the same period. The Lower UIB at Daggar and Karora is found to have a significantly reduced SSC in the months between March and May. During the months from June to October and especially from July to September, most of the glacierand snow-fed basins show a decrease in SSC. The Gilgit at Gilgit (Hindukush) and Alam Bridge (Gilgit + Hunza), Shoyk River at Yogo (Western Karakorum), and the Indus at Shatial Bridge (main UIB), Kachura (main UIB), and Kharmong (Central Karakorum) show a significant reduction of SSC in the months between June and September with no significant trend in discharges in the same period. In the month of November, the upper glacier- and snow melt-dominated basins of Gilgit at Gilgit (Hindukush), Gilgit at Alam Bridge (Gilgit + Hunza), and Astore at Doyian (Western Himalayas) show a significant increase of SSC. The SSC in the Lower UIB, i.e., in Brandu River at Daggar (Lower UIB in the West) is found to be reduced significantly per decade with an insignificant reduction of discharges during the months of July and August.

The seasonal and annual percentage changes per decade in mean values of SSC on a temporal and spatial basis in the UIB are presented in Table 7, Figures 3 and 4b. Table 7 and Figure 3 show that during the winter season, SSC values increase significantly by $20 \%-40 \%$ for the basins of Gilgit at Gilgit (Hindukush), Hunza at Dainyor (Western Karakorum), Gilgit at Alam Bridge (Gilgit+Hunza), Astore at Doyian (Western Himalayas), and the Indus at Shatial Bridge (main UIB) and Partab Bridge (main UIB) in the UIB. During the spring season, the basins of Astore at Doyian (Western Himalayas) and Indus at Shatial Bridge (main UIB) and Partab Bridge (main UIB) also show a significant increase in SSC in the range of $14 \%-33 \%$ per decade in mean values. In the rainfall-dominated lower basin of Brandu at Daggar (Lower UIB in the West), however, the SSC decreases by up to $16.8 \%$ of its mean value per decade. During the summer season, the SSC levels in the UIB decrease significantly at most of the stations, such as Gilgit at Gilgit, Hunza at Dainyor, Gilgit at Alam Bridge, Shigar at Shigar, Shyok at Yogo, Indus at Kachura, and Brandu at Daggar. In this period, the SSC values of Gilgit at Gilgit (Hindukush), Gilgit at Alam Bridge (Gilgit + Hunza), Kachura (main UIB), and Brandu at Daggar are reduced by 18 to $28 \%$ of their mean values per decade. In the autumns, the SSC trends for Gilgit at Alam Bridge (Gilgit + Hunza), Kachura (main UIB), and Brandu at Daggar are also significantly reduced by $15 \%-28 \%$. As obvious from Figure $4 \mathrm{~b}$, the annual SSC trends at most of the stations in the UIB decrease except for Astore at Doyian (Western Himalayas), Kharmong (Central Himalayas), and Indus at Shatial Bridge (main UIB). Figure $4 \mathrm{~b}$ and Table 7 show that the annual SSC trends of Gilgit at Alam Bridge (Gilgit + Hunza), Indus at Kachura, and Brandu at Daggar) decrease significantly by $18 \%-28 \%$ per decade with no significant reduction of discharges except for Brandu at Daggar. 

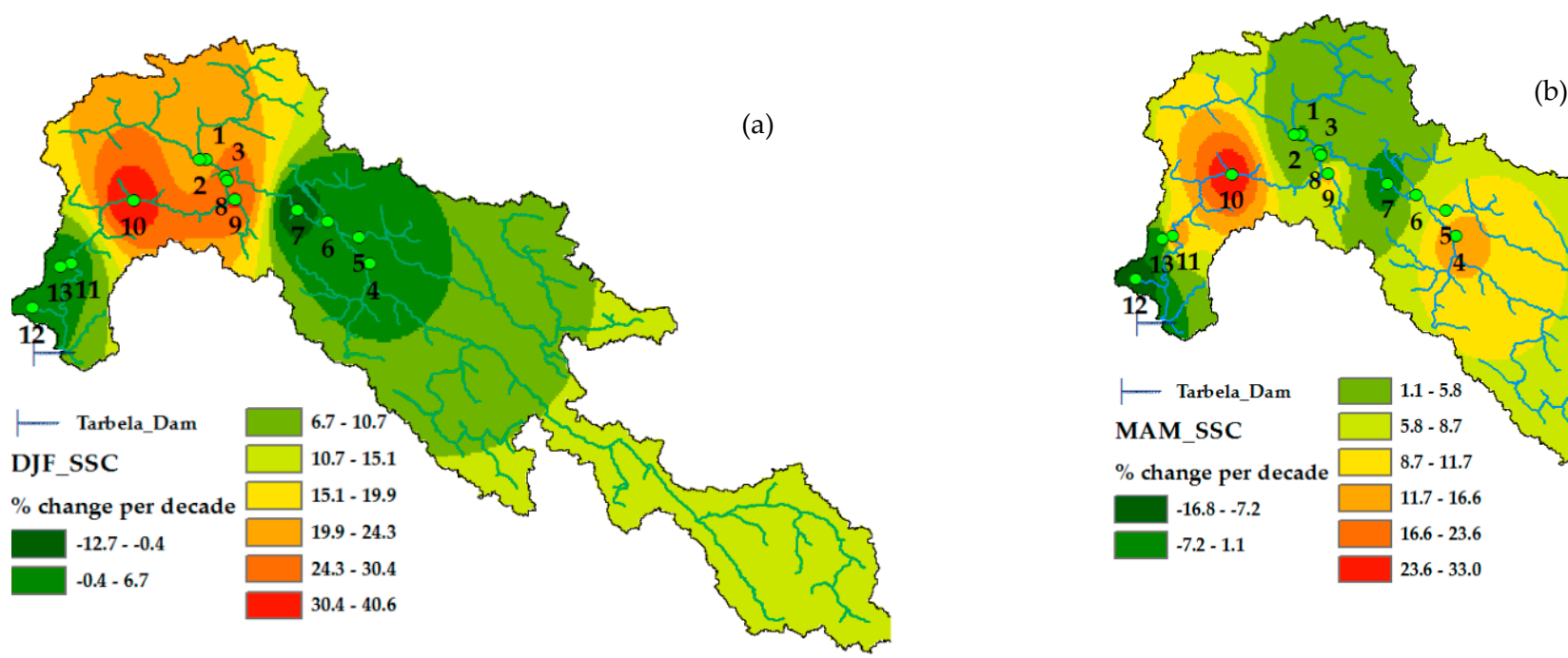

(b)
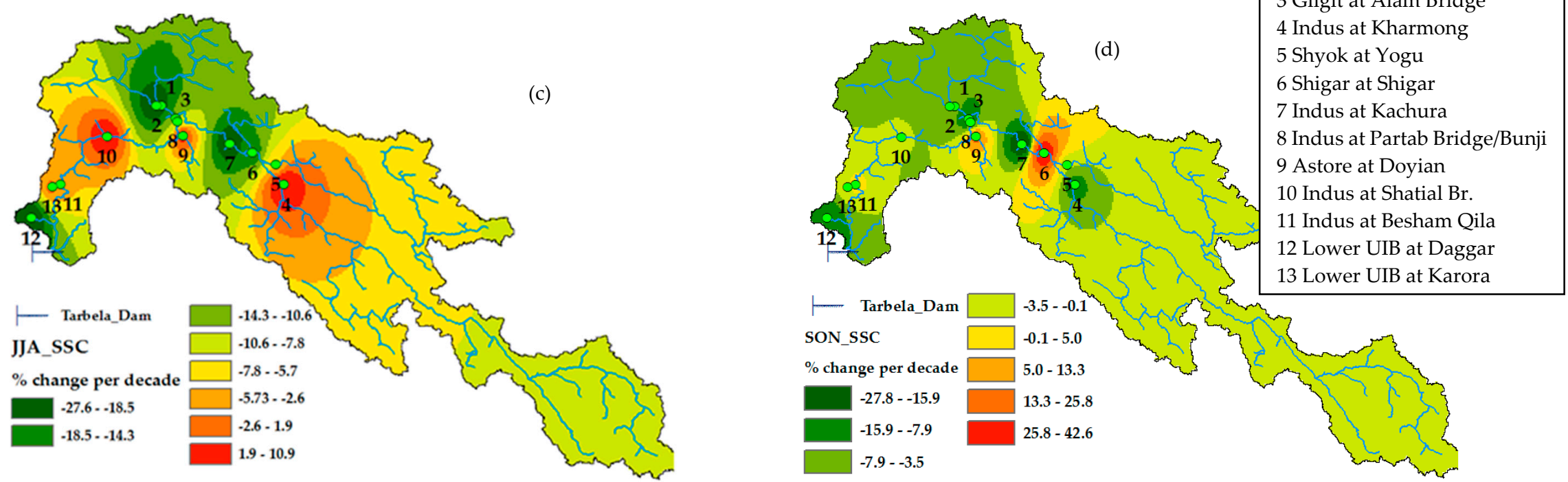

Figure 3. Seasonal suspended sediment concentration (SSC) trends spatially distributed over the basin with \% of changes per decade in \% of mean values for the whole period. (a) DJF (winter), (b) MAM (spring), (c) JJA (summer), (d) SON (autumn) seasons. 

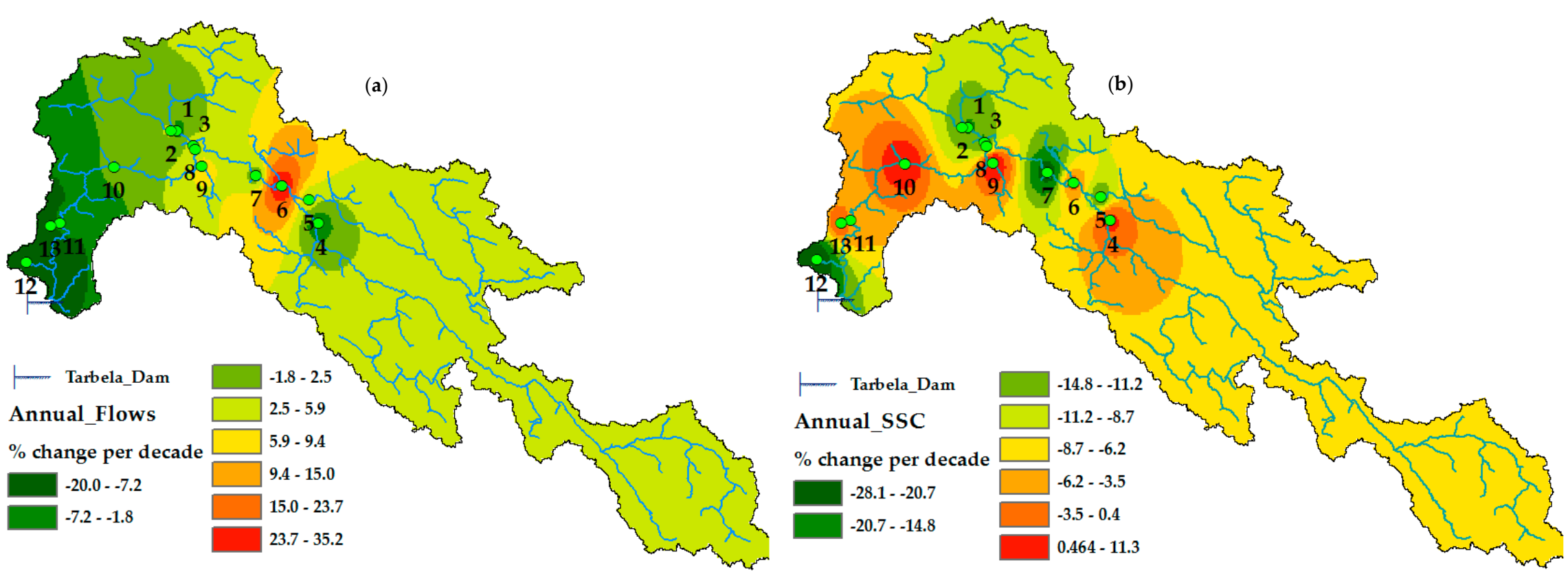

Figure 4. Annual flow and suspended sediment concentration (SSC) trends spatially distributed over the basin with \% of changes per decade in \% of mean values for the whole period. (a) Annual flows, (b) annual SSC. 


\subsection{Mean Basin Precipitation Trends}

Total changes in the basin's monthly precipitation (mm) for three decades (1981-2010) are shown in Table 8. In the winter months from December to January, there is an increase of precipitation in most of the basins probably due to increase of westerlies rainfall. In the month of February, Gilgit at Alam Bridge (Gilgit + Hunza) shows a significant increase in the basin-averaged precipitation, which is probably due to the effect of the Western front of the Hindukush during winters. During the spring months of March and April, precipitation is lowest, except in the Gilgit (Hindukush) basin. The month of March is the driest period in all basins.

In the springs, the basins of Gilgit at Gilgit (Hindukush) and Gilgit at Alam Bridge (Gilgit + Hunza) show a very wet period in the month of April. However, the Shyok at Yogo (Easter Karakorum), Astore at Doyian (Northwestern Himalayas), Brandu at Daggar (Lower UIB in the West), and Gorband at Karora (Lower UIB in the West) exhibit the driest trends in March. Drying in March can be found at almost all stations, except for Shigar. During the summer seasons, most of the stations show an increase in rainfall. The stations of Gilgit at Gilgit (Hindukush) and Gilgit at Alam Bridge (Gilgit + Hunza) record a significant increase in rainfall in the months of June and July. During the summer months, however, the rainfall-dominated basins of Brandu at Daggar (Lower UIB in the West) and Gorband at Karora (Lower UIB in the West) show reduced rainfall, except for the month of June. In the autumns, from September to November, there is an increase of precipitation in the UIB. In the month of October, however, precipitation generally is reduced in the UIB. 
Table 8. Total changes in monthly precipitation (mm) extracted from the grid data for the Upper Indus Basin (UIB) from 1981 to 2010.

\begin{tabular}{|c|c|c|c|c|c|c|c|c|c|c|c|c|c|c|c|}
\hline Ser\# & Basin & Region & Elevation $(\mathrm{m})$ & January & February & March & April & May & June & July & August & September & October & November & December \\
\hline 1 & Hunza & Western Karakorum & 3996 & 0.0 & 0.0 & 0.0 & 0.3 & 0.0 & 0.9 & -0.1 & 0.5 & 0.2 & 0.0 & 0.0 & 0.0 \\
\hline 2 & Gilgit & Hindukush & 4053 & 27.6 & 38.8 & -5.4 & 122.6 & 12.1 & 44.6 & 29.2 & 17.2 & 11.9 & -0.8 & 11.8 & -4.4 \\
\hline 3 & Alam Br. & Hunza + Gilgit & 4550 & 39.4 & 49.5 & -21.4 & 96.7 & 6.3 & 41.4 & 17.8 & 14.0 & 8.0 & -3.0 & 6.9 & -5.5 \\
\hline 4 & Kharmong & Central Himalayas & 4798 & 8.7 & -28.8 & -95.4 & -23.1 & 0.1 & 14.3 & -21.4 & 5.9 & 3.9 & -0.8 & 6.8 & -1.1 \\
\hline 5 & Shyok & Eastern Karakorum & 5094 & 4.7 & -16.3 & -103.0 & 5.6 & -3.4 & 1.0 & -20.8 & 17.6 & 13.3 & -2.3 & 2.3 & -11.6 \\
\hline 6 & Shigar & Central Karakorum & 4497 & 241.3 & 256.7 & 104.5 & 88.3 & 84.4 & 44.1 & 41.0 & -26.5 & 49.2 & -13.1 & -1.3 & -38.9 \\
\hline 7 & Kachura & Main River UIB & 4922 & 27.8 & 47.8 & -86.2 & 32.0 & -1.9 & 9.9 & -1.6 & 16.8 & 9.3 & -2.0 & 5.0 & -1.8 \\
\hline 8 & Bunji & Main River UIB & 4541 & 24.7 & 61.0 & -81.2 & 50.2 & -2.1 & 9.4 & 1.8 & 14.6 & 8.1 & -1.0 & 4.9 & 0.3 \\
\hline 9 & Astore & $\begin{array}{l}\text { North Western } \\
\text { Himalayas }\end{array}$ & 3996 & 48.9 & 57.1 & -174.3 & 45.6 & -10.7 & 11.5 & 1.2 & -10.3 & -1.7 & -13.8 & 0.2 & -11.9 \\
\hline 10 & Shatial & Main River UIB & 4488 & 26.3 & 56.0 & -83.1 & 46.8 & -2.7 & 8.7 & 0.9 & 15.2 & 8.5 & -1.7 & 5.1 & -0.9 \\
\hline 11 & $\begin{array}{l}\text { Besham } \\
\text { Qila }\end{array}$ & Main River UIB & 4312 & 26.2 & 56.3 & -83.1 & 47.0 & -2.8 & 8.8 & 0.9 & 14.9 & 8.5 & -1.7 & 5.1 & -0.5 \\
\hline 12 & Daggar & Lower Western UIB & 1111 & 5.9 & 25.2 & -178.1 & -48.6 & -19.5 & 35.4 & -7.1 & -50.5 & 12.1 & -23.4 & 8.5 & -19.6 \\
\hline 13 & Gorband & Lower Western UIB & 2257 & 21.9 & 6.9 & -217.1 & -45.1 & -22.4 & 43.9 & -20.1 & -42.3 & 11.5 & -25.3 & 12.8 & -25.1 \\
\hline 14 & Tarbela & UIB & 4421 & 25.7 & 29.7 & -107.9 & 27.2 & -19.7 & 14.8 & -8.5 & 2.2 & 2.2 & -6.1 & 2.7 & -9.2 \\
\hline
\end{tabular}

Note: Values in a box and written in bold represent the highest values of rainfall in mm with $90 \%$ significant level. Red color reflects the months of reduced precipitation (driest), blue color indicates the months with highest increased of precipitations (wettest). 


\subsection{Mean Monthly Average Temperature Trends}

Table 9 shows the change in mean monthly average temperature $\left({ }^{\circ} \mathrm{C}\right)$ between 1981 and 2010. The temperature trends of 18 meteorological stations located at different altitudes in UIB are shown with ascending altitude. Generally, most of the stations at higher and lower altitudes of the UIB show warming trends during the months of February and March. The Gilgit station at $1460 \mathrm{~m}$ altitude shows a significant increase in average temperature in the range of $1.23-3.02{ }^{\circ} \mathrm{C}$ during the months of January, February, and March. During the months of February, March, and April, the average temperature increases by $0.58-4{ }^{\circ} \mathrm{C}$ at altitudes from $1250 \mathrm{~m}$ to $4440 \mathrm{~m}$. In the late springs and early summers, i.e., in the months of May and June, there is an insignificant increase of average temperature at most of the higher and lower altitudes of the UIB. During summers and early autumns, i.e., in the months of July, August, and September, however, there is generally a cooling trend ranging from $0.03-1.87^{\circ} \mathrm{C}$. The stations of Gilgit in Giglit (Hindukush), Gupis in Gilgit (Hindukush), Chillas (Main UIB), and Skradu (Main UIB) show a significant decrease of average temperature by $1.34-1.87^{\circ} \mathrm{C}$ during summers and early autumns. In the late autumns, average temperature increases again. In the months of October and November, temperatures at higher altitudes increase at higher rates $\left(0.97-2.38^{\circ} \mathrm{C}\right)$ than valley stations (Table 9). 
Table 9. Changes in mean monthly averaged temperatures $\left({ }^{\circ} \mathrm{C}\right)$ from 1981 to 2010 for stations located at different altitudes in the Upper Indus Basin (UIB).

\begin{tabular}{|c|c|c|c|c|c|c|c|c|c|c|c|c|c|c|c|}
\hline Ser \# & Station & Sub-Basin & Elevation $(\mathrm{m})$ & January & February & March & April & May & June & July & August & September & October & November & December \\
\hline 1 & Chilas & $\begin{array}{l}\text { Besham } \\
\text { Qila }\end{array}$ & 1250 & 0.54 & 0.72 & 2.35 & -0.13 & 0.24 & -28 & -1.12 & -1.68 & -1.16 & 0.77 & 0.24 & -0.06 \\
\hline 2 & Bunji & Partab Br. & 1372 & 1.08 & 1.46 & 3.23 & 0.52 & 0.98 & 0.31 & -1.05 & -1.21 & -0.13 & 0.99 & 1.12 & 0.58 \\
\hline 3 & Gilgit & Gilgit & 1460 & 1.23 & 1.89 & 3.02 & 0.23 & 0.92 & 0.64 & -1.11 & -1.34 & -0.50 & 0.61 & 0.97 & 0.76 \\
\hline 4 & Shangla & Gorband & 1960 & 0.99 & 1.52 & 3.24 & 1.63 & 1.51 & 0.21 & 0.31 & 0.18 & -0.08 & 1.08 & 0.82 & 0.68 \\
\hline 5 & Gupis & Gilgit & 2156 & -0.26 & -0.14 & 1.79 & -0.35 & -0.28 & -0.01 & -1.87 & -1.29 & -0.53 & 2.44 & 0.98 & -0.47 \\
\hline 6 & Astore & Astore & 2168 & 0.98 & 2.43 & 3.13 & 1.30 & 0.94 & 1.48 & 0.00 & -0.51 & 0.27 & 1.01 & 1.67 & 0.61 \\
\hline 7 & Skardu & Shigar & 2210 & -0.69 & -1.03 & -0.26 & 0.36 & 0.83 & 0.92 & 0.08 & -0.68 & -0.43 & 0.69 & 0.58 & -0.05 \\
\hline 8 & Skardu & $\begin{array}{l}\text { Main } \\
\text { Kachura }\end{array}$ & 2210 & 1.11 & 1.63 & 1.87 & 0.29 & -0.21 & -0.01 & -0.80 & -0.92 & -1.60 & -0.35 & 0.83 & -0.23 \\
\hline 10 & Naltar & Hunza & 2898 & 1.16 & 1.74 & 2.86 & 1.29 & 0.66 & 1.26 & 0.16 & 0.32 & 0.36 & 1.86 & 1.63 & 0.60 \\
\hline 11 & Ziarat & Hunza & 3020 & 1.18 & 1.99 & 3.05 & 1.46 & 0.69 & 1.21 & 0.37 & 0.46 & 0.49 & 1.85 & 2.16 & 1.25 \\
\hline 12 & Ushkore & Gilgit & 3051 & 1.07 & 2.20 & 2.68 & 1.43 & 0.66 & 0.95 & -0.27 & -0.06 & -0.16 & 1.95 & 1.19 & 0.34 \\
\hline 13 & Hushey & Shyok & 3075 & 0.81 & 1.77 & 3.54 & 1.47 & 1.12 & 0.82 & 0.70 & 0.56 & 0.74 & 1.67 & 1.80 & 1.27 \\
\hline 14 & Rama & Astore & 3179 & 1.02 & 1.88 & 3.17 & 1.58 & 0.93 & 0.60 & 0.46 & 0.30 & 0.18 & 1.60 & 0.99 & 0.50 \\
\hline 15 & Yasin & Gilgit & 3280 & 1.13 & 1.56 & 2.81 & 1.20 & 0.69 & 1.47 & -0.23 & 0.04 & -0.20 & 1.47 & -0.02 & -1.44 \\
\hline 16 & Shendure & Gilgit & 3712 & 1.20 & 1.98 & 2.17 & 1.23 & 0.80 & 0.95 & -0.03 & 0.03 & -0.21 & 2.07 & 0.59 & 0.20 \\
\hline 17 & Desosai & Kharmong & 4149 & 1.00 & 1.53 & 3.15 & 1.56 & 1.23 & 1.35 & 1.06 & 0.24 & 0.44 & 1.86 & 1.20 & 0.71 \\
\hline 18 & Khunjrab & Hunza & 4440 & 1.38 & 1.87 & 4.00 & 1.79 & 1.56 & 1.37 & 0.22 & 0.44 & 0.66 & 2.01 & 2.38 & 1.01 \\
\hline
\end{tabular}

Note: Values in a box and written in bold represent the highest values of average temperature $\left({ }^{\circ} \mathrm{C}\right)$ at station altitudes with $90 \%$ significant level. Red color reflects an increase in monthly temperature (warming), blue color indicates decrease in monthly temperature (cooling). 


\subsection{Pearson's Correlations between Flows, SSC and Gridded Climatic Variables}

To evaluate the dominancy of different hydro-climatic variable in flows and sediment generation process the correlation between these variables was find out. The Table 10 shows the results of Pearson's correlations coefficients between the daily flows, SSC and gridded basin averaged rainfall and basin averaged mean air temperature. The Table 10 describes that correlation coefficient between flows and SSC is more significant on main Indus River for example; Indus at Shatial Bridge and Indus at Besham Qila. However, in the glacier and snow dominated basins, the correlation between flows and SSC is less significant in most of the sub basins compared to the main Indus River. Similarly, in lower UIB sub basins, the correlation between flows and SSC is least significant.

Table 10. Pearson's correlations between daily flows, SSC and gridded climatic datasets since 1981-2010 in the Upper Indus Basin (UIB).

\begin{tabular}{|c|c|c|c|c|c|}
\hline \multirow{2}{*}{ Ser \# } & \multirow{2}{*}{$\begin{array}{c}\text { Discharge Gauging } \\
\text { Stations }\end{array}$} & \multirow{2}{*}{ Region } & \multicolumn{3}{|c|}{ Pearson Correlations } \\
\hline & & & $Q$ vs. SSC & Q vs. R & Q vs. Tavg \\
\hline 1 & Hunza at Dainyor & Western Karakorum & 0.51 & -0.01 & 0.77 \\
\hline 2 & Gilgit at Gilgit & Hindukush & 0.73 & 0.04 & 0.82 \\
\hline 3 & Gilgit at Alam Bridge & Hunza + Gilgit & 0.64 & -0.06 & 0.80 \\
\hline 4 & Indus at Kharmong & Central Himalayas & 0.23 & 0.14 & 0.79 \\
\hline 5 & Shyok at Yogu & Eastern Karakorum & 0.46 & 0.06 & 0.74 \\
\hline 6 & Shigar at Shigar & Central Karakorum & 0.49 & -0.02 & 0.72 \\
\hline 7 & Indus at Kachura & Main River UIB & 0.68 & -0.14 & 0.79 \\
\hline 8 & Astore at Doyian & $\begin{array}{c}\text { North Western } \\
\text { Himalayas }\end{array}$ & 0.27 & 0.04 & 0.71 \\
\hline 9 & $\begin{array}{l}\text { Indus at Partab } \\
\text { Bridge/Bunji }\end{array}$ & Main River UIB & 0.62 & 0.03 & 0.77 \\
\hline 10 & Indus at Shatial Br. & Main River UIB & 0.75 & 0.03 & 0.80 \\
\hline 11 & Indus at Besham Qila & Main River UIB & 0.73 & 0.01 & 0.80 \\
\hline 12 & Lower UIB at Daggar & Lower western UIB & 0.47 & 0.37 & 0.05 \\
\hline 13 & Lower UIB at Karora & Lower western UIB & 0.11 & 0.13 & 0.11 \\
\hline
\end{tabular}

The correlation coefficient between flows/SSC and gridded basin averaged rainfall is non-significant on main Indus River as well as at glacierized snow and ice melted dominated sub basins. However, in lower UIB at Daggar the gridded basin averaged rainfall is better correlated than temperature. The gauging stations lying on the main Indus River as well in snow and ice melted sub basins showed significant correlations between flows/SSC and gridded basin averaged mean air temperature. Ali K.F et al. [37] found that the percent of snow/ice cover (LCs) is major land cover controlling parameter along with temperature and seasonal rainfall. Ali K.F et al. [37] also found that the combination of snow/ice cover (LCs) and climatic variables explain 98.5\% of variance in sediment yield in UIB. Similarly, for the lower monsoon dominated UIB, the mean annual rainfall explains the $99.4 \%$ of variance in sediment yields.

\section{Discussion}

Except for Kharmong and Astore, the annual trends of the SSC in the glacier- and snow-dominated basins of the UIB decrease in the months of July, August, and September, which is due to less snow/glacial melt in the cooler summer, as was reported by researchers $[7,8,38,39]$. In contrast to the SSC trend, an insignificant increase or no change in annual flows is detected, as is shown in Tables 6 and 7. Despite the cooler summer that leads to fewer discharges in glacierized upper basins like Hunza, Kharmong, and Astore, the absence of a significantly negative trend at Besham Qila indicates that this decrease is compensated by increased discharges from other sub-basins of the UIB.

During the winter season, Gilgit (Hindukush) and Hunza (Western Karakorum) show a significant increase of SSC along with discharges. This might be associated partly with a significant increase in the average winter temperature and an insignificant increase of precipitation due to westerlies in winter. 
Increasing temperature increases the snow melting rates and reduces seasonal precipitation in the form of snow during winters, which may lead to increased erosions in the catchment. A similar trend of an increase in SSC during the winter is observed for the basins of Astore (Northwestern Himalayas), Gilgit at Alam Bridge (Hunza + Gilgit), Indus at Partab Bridge (Main UIB), and Indus at Shatial Bridge (Main UIB), along with a significant increase of average temperature in the UIB.

During the spring season, the Astore at Doyian (Northwestern Himalayas), Indus at Shatial Bridge (Main UIB), Indus at Besham Qila (UIB), as well as Gilgit at Alam Bridge show a significant increase of SSC with a major increase in flows. The Indus at Kharmong and Shigar at Yogo show an insignificant increase of SSC and discharges. The increased flows in the river might result in an increase in effective discharges and erosion of the deposited sediments. Moreover, the sources of sediments in the glacial and snow melt-dominated catchments might be activated by rapid melting of snow accumulated in winter because of increasing temperatures in February and March. In the lower rainfall-dominated Daggar basin (Lower UIB), however, the SSC in springs decreases significantly with decreasing flows, which could probably be due to a reduction of spring rainfall. Table 8 shows that the rainfall at Daggar, Gorband, and Besham Qila in the Lower UIB decreases significantly in March, April, and May.

During the summer season, the SSC decreases in glacier-dominated basins, such as Gilgit (Hindukush), Hunza (Western Karakorum), Shigar (Central Karakorum), and Shyok at Yogo. This reduction of SSC in the summer at Gilgit (Hindukush) could be due to significant cooling of the summer temperature (Indus climate anomaly). Cooling of the summer temperature can be observed up to 3000 $m$ altitude in the Gilgit basin. As in the UIB, many glaciers are located at elevations from 2500 to 7000 $\mathrm{m}$. Seasonal snow accumulates in the elevation zone from $3000 \mathrm{~m}$ to $7000 \mathrm{~m}$. Furguson [50] describes that in UIB the mass movement, supraglacial and sub glacial sediments transport supply large amount sediments in valley. These sediments are stored in alluvial fans, outwash trains and moraines. The sediment is mainly transported by snow and ice melt process. Collins [51] estimated that for Hunza basin and Indus at Bashem Qila drives $60 \%$ and $40 \%$ of sediment loads annually from glacier melting. Own et al. [52] concluded that debris transport is an important contributor in glacierized regions of the UIB. Glacier debris transport yields a large amount of coarse rock debris and sediments from the basal traction zone. The debris-covered glacier in the UIB lies below $3000 \mathrm{~m}[36,40]$. This debris cover accelerates/deaccelerates melting $[53,54]$. This significant cooling of summer temperature up to $3000 \mathrm{~m}$ altitude probably reduces the supply of snow water from debris-covered glaciers and may increase the snow cover at lower and middle altitudes. This might result in a reduced SSC at the outlet. The Indus at Kachura also shows a decreasing trend of SSC over the entire year with a significant reduction in summers and autumns, which is probably also due to reduced temperatures and, hence, smaller snow water discharge rates in these months. In the Daggar (Lower UIB) basin, the SSC and flows are reduced significantly during summer, which is probably caused by a smaller rainfall intensity leading to smaller flows, sediment yields, and catchment erosion in the months of July and August.

In the autumn season, mixed trends of SSC are observed. Table 8 shows no significate change in precipitation during autumns. During the month of October, however, precipitation amounts generally are reduced in comparison to the precipitations of September and November. Moreover, as shown in Table 9, the month of September shows a lower average temperature at lower altitudes. So, the reduction of summer SSC from the UIB could probably be due to an increase in precipitation in the form of snow and a decrease of rainfall amount.

\section{Conclusions}

It may be concluded that the annual flows and SSC in the upper Indus Basin at Besham Qila are in a balanced state with a small reduction during the analysis period of three decades. However, the annual SSC values in the upper snow- and glacier-dominated Hindukush and Karakorum basins decrease, whereas the values of the mixed snow melt- and rainfall-dominated Western and Central Himalayan basins increase. The significant SSC reduction in the Hindukush and Western Karakorum basins during summers could be attributed to the Karakorum climate anomaly [7,8]. During winters, SSC values 
increase along with flows due to increasing temperatures in the glacier- and snow-dominated basins. In the lower basins of Daggar and Gorband near Besham Qila, the SSC and flows decrease significantly during the spring, autumn, and summer seasons when rainfalls decrease. Contrary to the summer's SSC pattern, the reduced SSC at Kachura, coupled with increasing trends of SSC at Partab Bridge and Shatial Bridge on the main River during winter and spring, confirming the findings of [55] that sediments are deposited in the summer and erosion takes place in winter and spring between Kachura and Besham Qila. Moreover, winter erosion might cause increasing trends of discharges in this area, which may enhance the capacity of the river to erode and transport the suspended sediment. Summer sediment deposition in this area in the absence of any significant discharge trends might be due to natural morpho-dynamic processes to compensate winter erosion and maintain the balanced flow regime. These findings improve understanding of the erosion process in different sub-basins of the UIB and, sediment erosion/deposition and transport in the Indus River. Now, sediment budgets can be determined in the light of climate change. Moreover, the analysis of altering patterns of precipitation, temperature, and flow and their impacts on the SSC values of different sub-basins of the UIB will be important for the management of existing (by developing appropriate reservoir operation scenarios), and the design of future hydraulic structures on the Indus and its tributaries in the UIB. This study will also help investigate the changing patterns of water quality, ecosystems, and geomorphology of the rivers of the UIB.

Author Contributions: W.U.H. designed the work, highlighted the problem, formulated the work plan, and analyzed the data. M.K.S. assisted in work plan formulation and helped in the interpretation of results, drafted the general outlines of the study in a coherent paper, and reviewed it. A.C. coordinated the grid data and extracted them. F.S. and F.N. assisted by providing practical knowledge and correcting the methodology. All authors have read and agreed to the published version of the manuscript.

Funding: This research received no external funding.

Acknowledgments: Funding of this work is supported by the German Academic Exchange Service (DAAD) and Higher Education Commission (HEC) of Pakistan. The Surface Water Hydrology Project (SWHP) of WAPDA and Pakistan Meteorological Department (PMD) provided the hydroclimatic data. We also acknowledge the support by the KIT-Publication Fund of the Karlsruhe Institute of Technology. We greatly appreciate their great support and help. The first author is also thankful to Walter Immerzeel and his team from the Department of Geosciences of Utrecht University for providing the corrected grid rainfall data for the Upper Indus Basin (UIB).

Conflicts of Interest: The authors declare no conflict of interest.

\section{References}

1. Milliman, J.D.; Syvitski, J.P.M. Geomorphic/Tectonic Control of Sediment Discharge to the Ocean: The Importance of Small Mountainous Rivers. J. Geol. 1992, 100, 525-544. [CrossRef]

2. Costa, A.; Molnar, P.; Stutenbecker, L.; Bakker, M.; Silva, T.A.; Schlunegger, F.; Lane, S.N.; Loizeau, J.L.; Girardclos, S. Temperature signal in suspended sediment export from an Alpine catchment. Hydrol. Earth Syst. Sci. 2018, 22, 509-528. [CrossRef]

3. Costa, A.; Anghileri, D.; Molnar, P. Hydroclimatic control on suspended sediment dynamics of a regulated Alpine catchment: A conceptual approach. Hydrol. Earth Syst. Sci. 2018, 22, 3421-3434. [CrossRef]

4. Babur, M. Assessment of Climate Change Impact on Reservoir Inflows Using Multi Climate Models under RCPs-The Case of Mangla Dam in Pakistan. Water 2016, 8, 389. [CrossRef]

5. Kreft, S.; Eckstein, D.; Melchior, I. Global Climate Risk Index 2017: Who Suffers Most From Extreme Weather Events? Weather-related Loss Events in 2015 and 1996 to 2015; Germanwatch Nord-Süd Initiative e V: Bonn, Germany, 2016; ISBN 978-3-943704-49-5.

6. Khan, N.M.; Tingsanchali, T. Optimization and simulation of reservoir operation with sediment evacuation: A case study of the Tarbela Dam, Pakistan. Hydrol. Process. 2009, 23, 730-747. [CrossRef]

7. Hewitt, K. The Karakorum Anomaly? Glacier Expansion and the ‘Elevation Effect,' Karakorum Himalaya. Mt. Res. Dev. 2005, 25, 332-340. [CrossRef]

8. Lutz, A.F.; Immerzeel, W.W.; Kraaijenbrink, P.D.A.; Shrestha, A.B.; Bierkens, M.F.P. Climate Change Impacts on the Upper Indus Hydrology: Sources, Shifts and Extremes. PLoS ONE 2016, 11, e0165630. [CrossRef] [PubMed] 
9. Yamamoto, R.; Iwashima, T.; Sanga, N.K.; Hoshiai, M. An Analysis of Climatic Jump. J. Meteorol. Soc. Jpn. 1986, 64, 273-281. [CrossRef]

10. Fu, C.B.; Wang, Q. The Definition and Detection of the Abrupt Climatic Change. Chin. J. Atmos. Sci. 1992, 16, 482-493.

11. Montgomery, D.C.; Peck, E.A. Introduction to Linear Regression Analysis; Wiley: New York, NY, USA; Chichester, UK, 1982; ISBN 0471058505.

12. Mann, H.B. Nonparametric Tests Against Trend. Econometrica 1945, 13, 245. [CrossRef]

13. Gerstengarbe, F.W.; Werner, P.C. Estimation of the beginning and end of recurrent events within a climate regime. Clim. Res. 1999, 11, 97-107. [CrossRef]

14. Bradley, J.V. Distribution-Free Statistical Tests; Prentice-Hall: Englewood Cliffs, NJ, USA, 1968.

15. Iman, R.L. Modern Approach to Statistics; Wiley: New York, USA, 1983; ISBN 978-0471096672.

16. Pettitt, A.N. A Non-Parametric Approach to the Change-Point Problem. Appl. Stat. 1979, 28, 126-135. [CrossRef]

17. Shen, D.; Bao, W.; Ni, P. A Method for Detecting Abrupt Change of Sediment Discharge in the Loess Plateau, China. Water 2018, 10, 1183. [CrossRef]

18. Ali, K.F.; De Boer, D.H. Spatial patterns and variation of suspended sediment yield in the upper Indus River basin, northern Pakistan. J. Hydrol. 2007, 334, 368-387. [CrossRef]

19. Ali, K.F.; De Boer, D.H. Construction of sediment budgets in large-scale drainage basins: The case of the upper Indus River. Iahs-Aish Publ. 2003, 279, 206-215.

20. Ali, K.F.; De Boer, D.H. Spatially distributed erosion and sediment yield modeling in the upper Indus River basin. Water Resour. Res. Water Resour. Res 2010, 46. [CrossRef]

21. Gao, P.; Zhang, X.; Mu, X.; Wang, F.; Li, R.; Zhang, X. Trend and change-point analyses of streamflow and sediment discharge in the Yellow River during 1950-2005. Hydrol. Sci. J. 2010, 55, 275-285. [CrossRef]

22. Ateeq-Ur-Rehman, S.; Bui, M.; Rutschmann, P. Variability and Trend Detection in the Sediment Load of the Upper Indus River. Water 2018, 10, 16. [CrossRef]

23. Tarar, Z.; Ahmad, S.; Ahmad, I.; Majid, Z. Detection of Sediment Trends Using Wavelet Transforms in the Upper Indus River. Water 2018, 10, 918. [CrossRef]

24. Meadows, A.; Meadows, P.S. The Indus River. Biodiversity, Resources, Humankind; Azra, M., Peter, S., Eds.; Oxford University Press for the Linnean Society of London: Oxford, UK, 1999; ISBN 0195779053.

25. Ahmad, N. Water Resources of Pakistan and Their Utilization; Nazir Ahmad; Shahzad Nazir: Lahore Pakistan, Pakistan, 1993.

26. Pakistan Water Sector Strategy. Executive Summary; Report; Ministry of Water and Power, Office of the Chief Engineering Advisor/Chairman Federal Flood Commission; Govt of Pakistan: Islamabad, Pakistan, 2002; Volume 1.

27. Pakistan Water Gateway. The Pakistan Water Situational Analysis; Report; Consultative Process in Pakistan (WCD CPP) Project; Pakistan Water Gateway: Islamabad, Pakistan, 2005.

28. Khan, A.; Richards, K.; Parker, G.; Mcrobie, F.; Mukhopadhyay, B. How large is the Upper Indus Basin? The pitfalls of auto-delineation using DEMs. J. Hydrol. 2014, 509, 442-453. [CrossRef]

29. Ali, G.; Hasson, S.u.; Khan, A. Climate Change: Implications and Adaptation of Water Resources in Pakistan, GCISC-RR-13, Global Change Impact Studies Centre (GCISC); Global Change Impact Studies Centre: Islamabad, Pakistan, 2009. [CrossRef]

30. Hewitt, K. Glacier Change, Concentration, and Elevation Effects in the Karakorum Himalaya, Upper Indus Basin. Mt. Res. Dev. 2011, 31, 188-200. [CrossRef]

31. Winiger, M.; Gumpert, M.; Yamout, H. Karakorum-Hindukush-western Himalaya: Assessing high-altitude water resources. Hydrol. Process. 2005, 19, 2329-2338. [CrossRef]

32. Batura Investigations Group. The Batura Glacier in the Karakorum Mountains and its variations. Sci. Sin. 1979, 22, 958-974.

33. Wake, C.P. Snow accumulation studies in the central Karakorum. In Proceedings of the Eastern Snow Conference 44th Annual Meeting, Fredericton, NB, Canada, 3-4 June 1987; pp. 19-33.

34. Hewitt, K. Tributary glacier surges: An exceptional concentration at Panmah Glacier, Karakorum Himalaya. J. Glaciol. 2007, 53, 181-188. [CrossRef]

35. Young, G.J.; Hewitt, K. Glaciohydrological features of the Karakorum Himalaya: Measurements possibilities and constraints. IAHS Publ. 1993, 218, 273-283. 
36. Khan, A.; Naz, B.; Bowling, L. Separating snow, clean and debris covered ice in the Upper Indus Basin, Hindukush-Karakorum-Himalayas, using Landsat images between 1998-2002. J. Hydrol. 2014, 521. [CrossRef]

37. Ali, K.F.; De Boer, D.H. Factors controlling specific sediment yield in the upper Indus River basin, northern Pakistan. Hydrol. Process 2008, 22, 3102-3114. [CrossRef]

38. Arfan, M.; Lund, J.; Hassan, D.; Saleem, M.; Ahmad, A. Assessment of Spatial and Temporal Flow Variability of the Indus River. Resources 2019, 8, 103. [CrossRef]

39. Hasson, S.U.; Böhner, J.; Lucarini, V. Prevailing climatic trends and runoff response from Hindukush-Karakorum-Himalaya, upper Indus Basin. Earth Syst. Dyn. 2017, 8, 337-355. [CrossRef]

40. Immerzeel, W.W.; Wanders, N.; Lutz, A.F.; Shea, J.M.; Bierkens, M.F.P. Reconciling high-altitude precipitation in the upper Indus basin with glacier mass balances and runoff. Hydrol. Earth Syst. Sci. 2015, 19, 4673-4687. [CrossRef]

41. Lutz, A.F.; Immerzeel, W.W. HI-AWARE Reference Component 1. Climate Dataset for the Indus, Ganges and Brahmaputra River Basins. FutureWater Rep. 2015, 146. Available online: https://www.futurewater.eu/wpcontent/uploads/2015/10/Report_IGB_historical_climate_dataset.pdf (accessed on 6 March 2018).

42. GLIMS, and National Snow and Ice Data Center. GLIMS Glacier Database. Glaciers in the Karakorum Mountain Region; National Snow and Ice Data Center: Boulder, CO, USA, 2012. [CrossRef]

43. Sinha, T.; Cherkauer, K.A. Time Series Analysis of Soil Freeze and Thaw Processes in Indiana. J. Hydrometeorol. 2008, 9, 936-950. [CrossRef]

44. Hamed, K.H.; Ramachandra Rao, A. A modified Mann-Kendall trend test for autocorrelated data. J. Hydrol. 1998, 204, 182-196. [CrossRef]

45. Kendall, M.G. Rank Correlation Methods, 4th ed.; Griffin: London, UK, 1970; ISBN 978-0-85-264199-6.

46. Ahmed, K.; Shahid, S.; Wang, X.; Nawaz, N.; Khan, N. Spatiotemporal changes in aridity of Pakistan during 1901-2016. Hydrol. Earth Syst. Sci. 2019, 23, 3081-3096. [CrossRef]

47. Gao, P.; Geissen, V.; Ritsema, C.J.; Mu, X.-M.; Wang, F. Impact of climate change and anthropogenic activities on stream flow and sediment discharge in the Wei River basin, China. Hydrol. Earth Syst. Sci. 2013, 17, 961-972. [CrossRef]

48. Sen, P.K. Estimates of the Regression Coefficient Based on Kendall's Tau. J. Am. Stat. Assoc. 1968, 63, 1379. [CrossRef]

49. Shahzad, M.K. Statistical Analysis of Inflows of River Indus at Tarbela in the Wake of Climate Change. In Proceedings of the International Conference on HYDROPOWER-A Vital Source of Sustainable Energy for Pakistan 2017, UET Lahore, Pakistan, 19-20 December 2017; pp. 19-27, ISBN 978-969-8670-06-01.

50. Ferguson, R.I. Sediment Load of the Hunza River; Mill, K.J., Ed.; International Karakoram Project Cambridge University Press: Cambridge, UK, 1984; Volume 2, pp. 580-598.

51. Collins, D.N. Sediment transport from glacierized basins in the Karakoram mountains. In Proceedings of the International Symposium, Exeter, UK, 15-19 July 1996; Volume 236, pp. 85-96, ISBN 0-947571-89-2.

52. Owen, L.A.; Edward, D.; Christine, H.S. Contemporary sediment production and transfer in high-altitude glaciers. Sediment. Geol. 2003, 155, 13-36. [CrossRef]

53. Kääb, A.; Berthier, E.; Nuth, C.; Gardelle, J.; Arnaud, Y. Contrasting patterns of early twenty-first-century glacier mass change in the Himalayas. Nature 2012, 488, 495-498. [CrossRef]

54. Nuimura, T.; Fujita, K.; Fukui, K.; Asahi, K.; Aryal, R.; Ageta, Y. Temporal Changes in Elevation of the Debris-Covered Ablation Area of Khumbu Glacier in the Nepal Himalaya since 1978. Arct. Antarct. Alp. Res. 2011, 43, 246-255. [CrossRef]

55. Ali, K.F. Construction of Sediment Budgets in Large Scale Drainage Basins: The Case of the Upper Indus River. Ph.D. Thesis, Department of Geography and Planning, University of Saskatchewan, Saskatoon, SK, Canada, 2009.

(C) 2020 by the authors. Licensee MDPI, Basel, Switzerland. This article is an open access article distributed under the terms and conditions of the Creative Commons Attribution (CC BY) license (http://creativecommons.org/licenses/by/4.0/). 